\title{
Variability and changes to the mean meridional circulation in isentropic coordinates
}

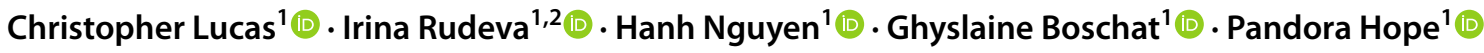

Received: 22 April 2021 / Accepted: 24 July 2021 / Published online: 3 August 2021

(c) Crown 2021

\begin{abstract}
We examine the climatology, variability and change in the global mean meridional circulation (MMC) as measured in a dry isentropic coordinate system from 1979-2017 using the ERA-Interim reanalysis. The methodology presents a zonal-mean view of the MMC as a single thermally direct circulation cell in each hemisphere. The circulation is decomposed into 'steady' and 'transient' components which allows us to identify and quantify several MMC features, including the Intertropical Convergence Zone, the descending branches of the Hadley circulation and a 'transient updraft' associated with the extratropical storm track. Large changes were identified in the Southern Hemisphere ( $\mathrm{SH})$ in both the Hadley Cell and the extratropical storm track in the late-1990s. These changes intertwine with the Interdecadal Pacific Oscillation that changed from a warm to a cold phase around 2000. Less significant changes were observed in the Northern Hemisphere, although high rates of tropical expansion during boreal summer may have been exacerbated by volcanic eruptions in the 1980s and 1990s. Further to those changes, tropical expansion was observed in autumn, with little change in the extratropical storm track. While potential inhomogeneities in the reanalysis limit the certainty about the magnitude of the identified changes, multiple nonreanalysis-based datasets suggest that large changes did occur in the 1990s in the $\mathrm{SH}$, supporting the presented analysis.
\end{abstract}

Keywords Atmospheric circulation $\cdot$ Isentropic analysis $\cdot$ Hadley cell $\cdot$ Extratropical circulation

\section{Introduction}

The role of the mean meridional circulation (MMC) in the global climate is to alleviate the global heating imbalance between the equator and poles (Oort and Yienger 1996). The large-scale circulations and weather-scale eddies both in the tropics and extratropics work together to transfer heat, momentum and water vapour from the tropics to the middle and high latitudes. In this process, radiative effects, water phase transitions and the resulting atmospheric dynamics act cumulatively to create the MMC. Examining the MMC and how it has changed both seasonally and over the past decades helps us identify possible drivers of those changes and how they are inter-connected globally.

Irina Rudeva

irina.rudeva@bom.gov.au

1 Australian Bureau of Meteorology, Melbourne, VIC, Australia

2 P.P. Shirshov Institute of Oceanology, Moscow, Russia
Most commonly, studies represent the MMC by calculating the vertical integral of the meridional mass flux to estimate the mass streamfunction in isobaric coordinates. This representation (Fig. 1a) yields a familiar 'three-cell' model of the MMC, dominated by the Hadley Cells (HC) in the tropics with the considerably weaker Ferrel and Polar cells in the extratropics (Oort and Yienger 1996). In recent years, many studies of the changing isobaric MMC have focused on the notion of tropical expansion (see Lucas et al. 2014; Seidel et al. 2008). The downward branch of the $\mathrm{HC}$ has been shifting poleward at a rate of $0.5^{\circ}$ to $2.0^{\circ}$ latitude decade ${ }^{-1}$ since 1979 , with the highest rates in the warm seasons (e.g. Grise et al. 2018, 2019; Hu and Fu 2007; Nguyen et al. 2013). Numerous proxies for the 'tropical edge' support this change (Waugh et al. 2018), including tropopause-based metrics from radiosonde data (Lucas et al. 2012; Lucas and Nguyen 2015; Seidel and Randel 2007) and satellite-based metrics (Fu et al. 2006). Furthermore, a number of studies (Davis and Birner 2017; Levine and Schneider 2015; Polvani et al. 2011; Solomon et al. 2016; Son et al. 2010; Waugh et al. 2018; Rudeva et al. 2019) showed that the width of the tropics is strongly linked to the 
(a) Isobaric

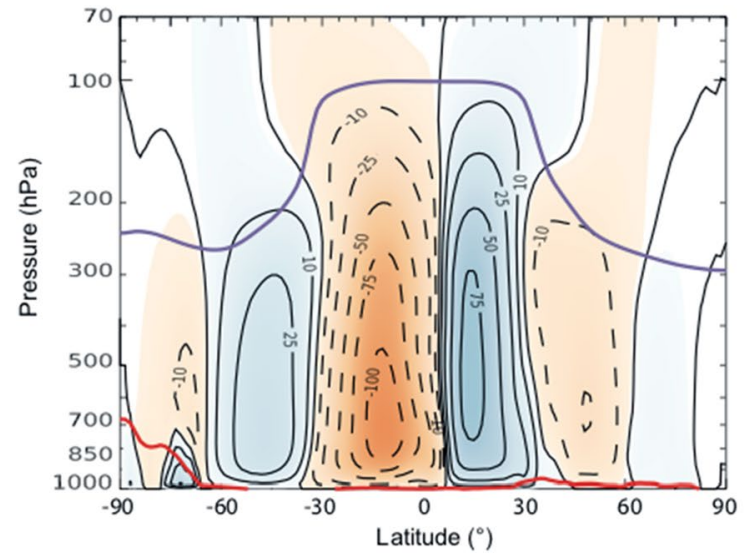

(c) Steady Isentropic

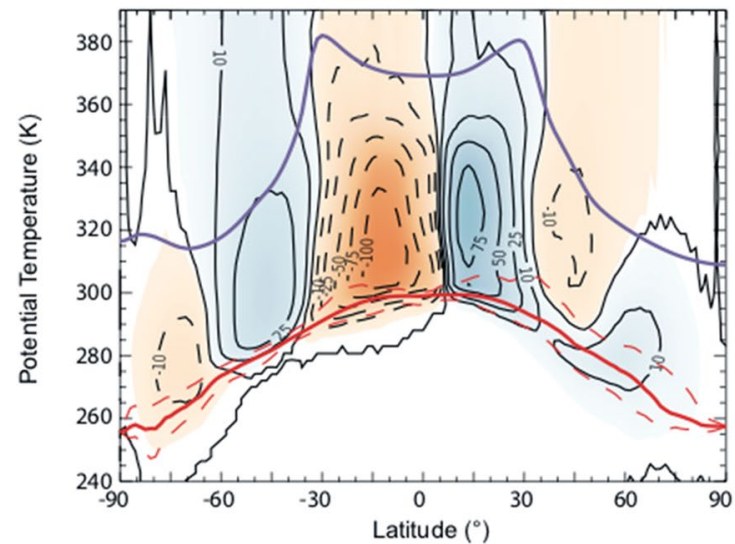

Fig. 1 Annual mean values of $\mathbf{a}$ isobaric, $\mathbf{b}$ full isentropic, $\mathbf{c}$ steady and $\mathbf{d}$ transient mass streamfunction for the period 1979-2017. Units are $10^{9} \mathrm{~kg} \mathrm{~s}^{-1}$. Following convention, the circulation is counterclockwise around negative centres (orange) and clockwise around positive centres (blue). Contours are spaced every 25 units, with an additional

midlatitude jet and extratropical synoptic systems. The rates of expansion are highly sensitive to the metric used, creating significant uncertainty in the estimates (Davis and Rosenlof 2012). A later study by Staten et al. (2018) re-examined the rates of tropical expansion and concluded that the rate of expansion at the surface level was around $0.5^{\circ}$ per decade.

The attribution of observed changes in the tropical width also remains uncertain, with some combination of greenhouse gases (Lu et al. 2007; Nguyen et al. 2015), ozone depletion (Polvani et al. 2011; Min and Son 2013; Gerber and Son 2014; Garfinkel et al. 2015), aerosol forcing (Allen et al. 2014; Kovilakam and Mahajan 2015) and natural sea surface temperature (SST) variability (Grassi et al. 2012; Allen et al. 2014; Brönnimann et al. 2015; Lucas and Nguyen 2015; Allen and Kovilakam 2017; Amaya et al. 2017) being identified as factors.

\section{(b) Full Isentropic}

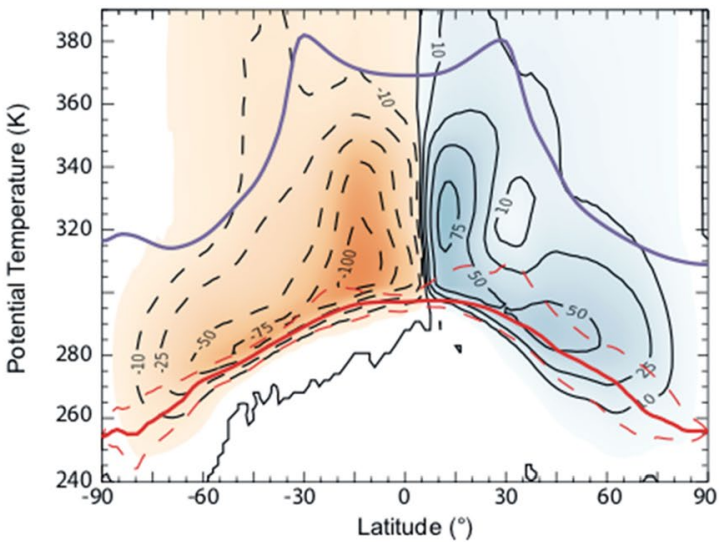

(d) Transient Isentropic

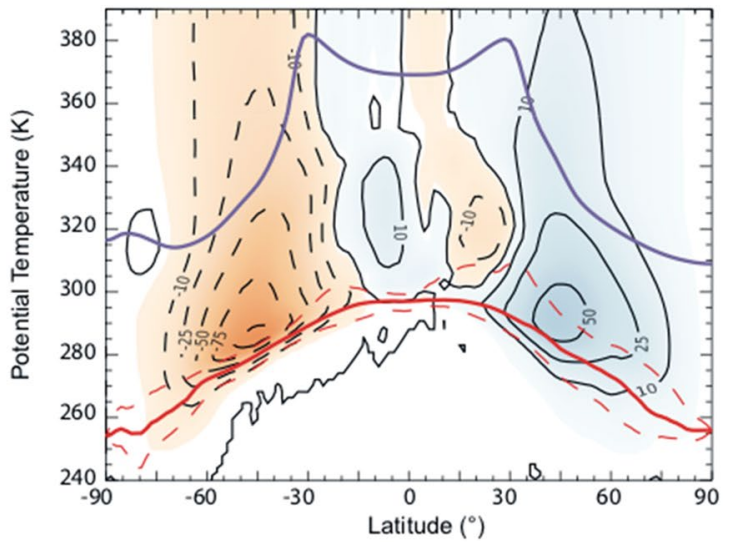

contour at \pm 10 units. The purple line represents the location of the average tropopause. In a the red line is the average zonal mean surface pressure. In b-d, the solid red line is the average median surface temperature, while the dashed lines are the average $10 \%$ and $90 \%$ values

These shifts are generally more persistent in the Southern Hemisphere (SH), and have been associated with the poleward displacement of the subtropical dry zones that bring an increased frequency of drought and heat waves to highly populated areas. A reduction in precipitation and frontal activity in the southern parts of Australia and Africa has been shown in many previous studies (Risbey et al. 2009; Cai et al. 2012; Cai and Cowan 2013; MacKellar et al. 2014; Frederiksen and Grainger 2015; Solman and Orlanski 2016; Turton 2017; Rudeva et al. 2019).

While the isobaric view of the MMC is informative, there are other approaches to calculating the mass streamfunction that reveal different aspects of the global atmospheric system. For example, Nakamura (1995) used potential vorticity in conjunction with potential temperature $(\theta)$ while Kjellsson et al. (2014) used purely thermodynamic coordinates (dry static energy vs latent heat). Another increasingly 
common calculation uses equivalent potential temperature $\left(\theta_{\mathrm{e}}\right)$ as the vertical coordinate to identify the moist isentropic MMC (Pauluis et al. 2008, 2010; Döös and Nilsson 2011; Laliberte et al. 2012; Wu et al. 2019) that provides insight into the important role of water vapour in the mid-latitudes. While these approaches have their own advantages, it is difficult to interpret their results in a geographical sense. For example, the mass transport in the moist isentropic view does not necessarily correspond to an overturning circulation in geometrical coordinates.

In this paper, we use the dry isentropic circulation, where $\theta$ is used as the vertical coordinate to represent the MMC (Townsend and Johnson 1985; Held and Schneider 1999; Schneider 2006; Robertson and Vitart 2019). While the dry isentropic circulation does not fully capture the energy transformations as well as the moist isentropic or thermodynamic coordinate systems (Kjellsson et al. 2014), it has the advantage that it is well defined in space, since the $\theta$ is vertically stratified in both the tropics and the extratropics. In this framework, the MMC is defined by a single thermally direct circulation cell in each hemisphere (Fig. 1b), as opposed to the isobaric "three-cell" view. The reason for this is that $\theta$ is materially conserved following adiabatic motion, which means that the isentropic-coordinate averages partition diabatic and adiabatic behaviours: mass transport is upward (downward) in a heat source (sink) region and air parcel displacements within large-scale midlatitude weather systems are predominantly along isentropic surfaces. In contrast, vertical motions across pressure levels can occur through both diabatic and adiabatic motions. As a result, the Ferrel cell, which appears as a thermally indirect circulation in the midlatitudes in the pressure-coordinate averages, is absent in the full isentropic coordinates (Townsend and Johnson 1985; Schneider 2006; Robertson and Vitart 2019).

In this paper, we first calculate the full isentropic MMC and then 'decompose' it into steady and transient components. Then, we present the annual mean and seasonal cycle of the dry isentropic atmospheric circulation (Sect. 3), in particular, the intensity and location of upward and downward branches of the HCs and transient circulations in both hemispheres, and then show their long-term variability and trends (Sect. 4). We also offer some insights on possible causes of the observed changes. Throughout the paper seasons will be referred to as that relevant to the hemisphere under discussion, if this is not entirely clear the terms 'austral' or 'boreal', or the series of months, will be added.

\section{Data and methods}

\subsection{Data}

The data used in this analysis are the European Centre for Medium-Range Weather Forecasts Interim Reanalysis (ERA-I) for the period 1979-2017 (Dee et al. 2011) with a horizontal resolution of $1.5 \times 1.5^{\circ}$. We use once-daily (at 12 UTC) and monthly mean three-dimensional fields of meridional wind and air temperature on 60 model levels from the surface to $\sim 1 \mathrm{hPa}$, with levels more highly concentrated near the surface. Pressure on the model levels is derived from the surface pressure.

\subsection{Dry isentropic circulation}

The isentropic streamfunction is computed following methods described in detail by (Juckes et al. 1994; Schneider et al. 2006; Townsend and Johnson 1985, hereafter TJ85). The domain used here consists of 90 staggered vertical isentropic levels extending from $\theta=210 \mathrm{~K}$ to $\theta=450 \mathrm{~K}$, covering the coldest air in the extratropical zones and extending into the lower stratosphere, ensuring the entire troposphere is captured.

Meridional wind $(v)$, pressure $(p)$ and temperature fields are interpolated onto isentropic coordinates using potential temperature $(\theta)$ as the vertical coordinate. From these interpolated fields, the meridional mass flux is computed using the isentropic density $\rho_{\theta}=-\frac{1}{g} \frac{\partial p}{\partial \theta}$, where $g$ is the gravitational acceleration. This field is zonally averaged, and the continuity equation is solved to produce the streamfunction $\Psi$ that describes streamlines of mass transport within the isentropic coordinate system. The isentropic streamfunction $\Psi$ is defined by:

$\Psi=-2 \pi a \cos \phi \int_{\theta_{b}}^{\theta} \overline{v \rho_{\theta}} d \theta$,

where overbar denotes zonal mean, $a$ is the equatorial radius of the Earth, $\phi$ is the latitude and $\theta_{b}$ is the potential temperature at the surface.

In the isentropic coordinate system, the diabatic heating $(Q)$ is directly related to the 'vertical', i.e., cross-isentropic, velocity, given by the meridional derivative of $\Psi$, and expressed following Schneider et al. (2006) as:

$\overline{\rho_{\theta}} Q=\frac{1}{2 \pi a^{2} \cos \phi} \frac{\partial \Psi}{\partial \phi}$.

A simple interpretation of the resulting diagrams is that regions with vertically oriented streamlines represent 
diabatic heating or cooling, while horizontally directed streamlines represent adiabatic flow.

Further, $\Psi$ can be decomposed into the time mean circulation, referred here as 'steady', and 'transient' components (Shaw and Pauluis 2012; Tanaka et al. 2004; Trenberth and Stepaniak 2003). TJ85 split the isentropic circulation into 'ageostrophic' and 'geostrophic' parts, that are similar to steady and transient components, respectively. The steady isentropic mass circulation reveals a direct HC in low latitudes and an indirect Ferrel circulation in midlatitudes, similar to that described by the isobaric streamfunction. The transient circulation represents the cumulative effects of baroclinic eddies in the midlatitudes. As discussed in TJ85, the critical difference between the isentropic and isobaric circulations is an out-of-phase relation between the mass distribution and meridional geostrophic wind in amplifying baroclinic waves, that can be seen in the isentropic framework. The computation of the flow based on $\theta$ allows these features to be distinguished, unlike in a traditional isobaric analysis (Fig. 1).

In this study, the full (steady) circulation is computed using daily (monthly mean) fields from the reanalysis. The steady circulation is not limited to the Eulerian mean circulation but also includes a contribution from stationary eddies. The transient flow is defined as the difference between the full and the steady streamfunctions.

\subsection{Defining MMC components using the vertical mass transport}

One property of streamfunctions is that the difference in $\Psi$ between any two points is equal to the mass transport normal to the line joining those points (Oort and Yienger 1996). Using this property, a useful quantitative metric can be defined by taking a simple difference of $\Psi$ at an isentropic level, yielding a profile of the vertical, or cross-isentropic, mass transport (VMT) as a function of latitude that is proportional to the diabatic heating/cooling rate. Figure 2 illustrates this calculation for the steady and transient circulations during March-May (MAM) 2014. After applying a seven-point running mean to dampen the observable noise, the VMT profile is used to identify broad regions of contiguous vertical motions. Each vertical branch is characterised by the width, total mass transport and position. They are defined as follows:

- The width is the difference in latitude between the beginning and ending of the branch, selected as the latitude where the smoothed VMT with the 7-point running average changes sign;

- The total mass transport (TMT) is the sum of all smoothed VMT values within a branch. This is proportional to the heating rate of the branch;
Fig. 2 The vertical mass transport (VMT) profiles $\left(10^{9} \mathrm{~kg} \mathrm{~s}^{-1}\right)$ in MAM 2014: a at $320 \mathrm{~K}$ for the steady and $\mathbf{b}$ at $300 \mathrm{~K}$ for the transient fields. Thin lines represent the unsmoothed values; thick lines are the values with a 7-point smoothing applied ( $10.5^{\circ}$ latitude). Red and blue hatching represents regions of upward and downward motion, respectively. Vertical arrows represent the position of seven key indicators as defined in the text, while TMT presents the total mass transport $\left(10^{9} \mathrm{~kg} \mathrm{~s}^{-1}\right)$. See

Table 1 for notations (a) VMT for steady field (at $320 \mathrm{~K}$ )

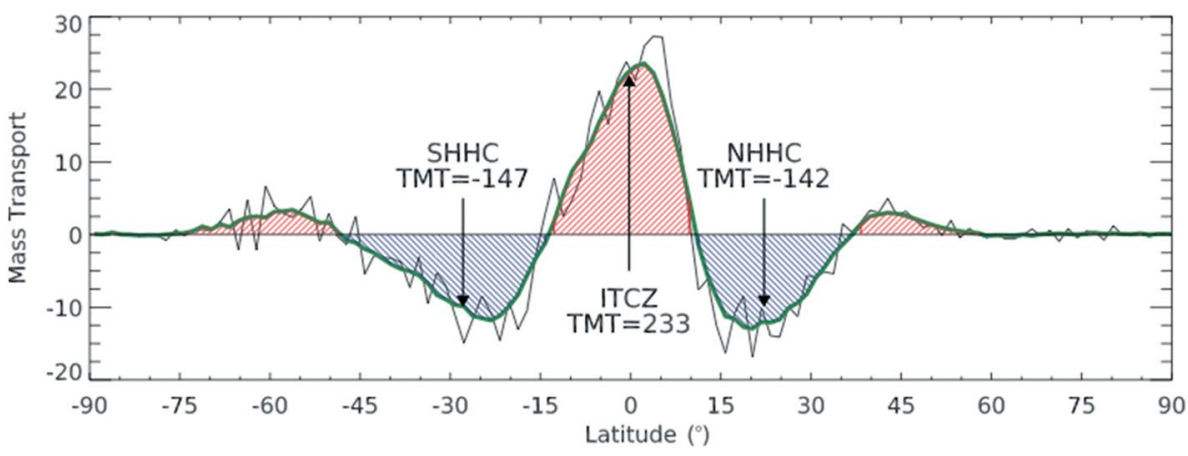

(b) VMT for transient field (at $300 \mathrm{~K}$ )

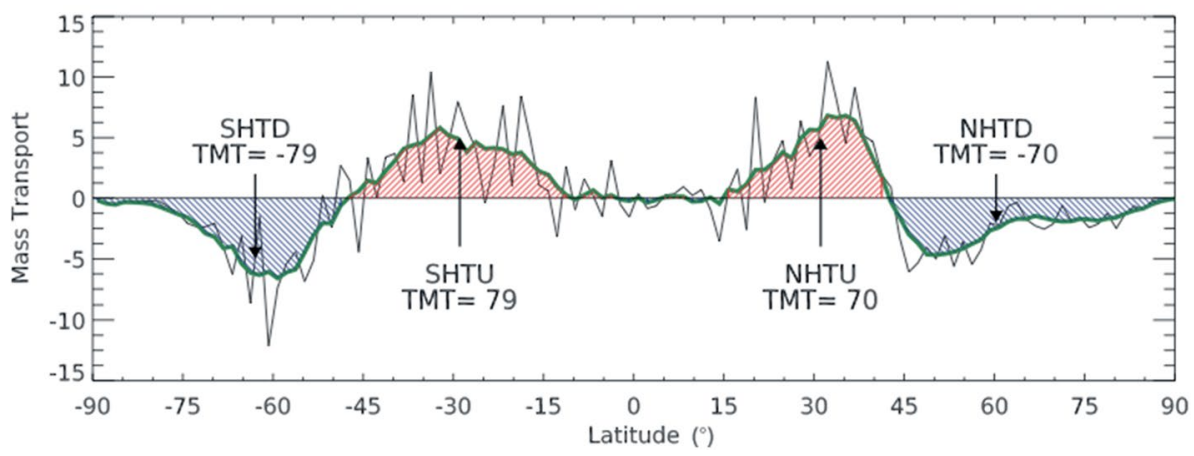


- The position is the mass transport-weighted mean latitude of a given branch. It measures the centroid of the heating.

From the VMT profiles for each season, we quantify seven components of the MMC. From the 'steady' VMT at $320 \mathrm{~K}$, a level in the tropical mid-troposphere (Fig. 2a), the upward motion near the equator represents the Intertropical Convergence Zone (ITCZ) and the two flanking downward motions represent the descending branches of HCs, termed the HC edges. Similarly, from the transient mass transport fields (Fig. 2b) we define the transient updrafts at $300 \mathrm{~K}$ in the subtropics of each hemisphere, and a transient downdraft closer to the pole. While the transient downdraft is readily apparent at $300 \mathrm{~K}$, in our calculation we use the VMT profile at $280 \mathrm{~K}(\mathrm{SH})$ or $285 \mathrm{~K}(\mathrm{NH})$ where the overall VMT is stronger. The higher $\theta$ in the $\mathrm{NH}$ is reflective of warmer $\mathrm{NH}$ in higher latitudes relative the SH. Definitions of these components are presented in Table 1. Unlike many metrics representing the MMC, these metrics depend on the relative variation within the circulation rather than an absolute value or position, and as such should be more resilient to any external biases within the ERA-I.

\subsection{Tropopause height}

The tropopause level is calculated following the algorithm described by Reichler et al. (2003) as the lowest level where the lapse rate is $2 \mathrm{~K} \mathrm{~km}^{-1}$ or less extending for a depth of $2 \mathrm{~km}$. The calculation is performed on the ERA-I monthly mean data.

\section{Climatology of the Isentropic MMC}

\subsection{Annual mean meridional circulation}

The annual mean $\Psi$ (Fig. 1b) provides an overview of the isentropic representation of the meridional circulation. In contrast to the 'three cell' isobaric circulation, the isentropic circulation has one prominent 'lobe' in each hemisphere (compare Fig. 1a, b). Strong upward vertical motion near the equator indicates a diabatic heat source from the strong latent heating associated with deep convection in the ITCZ. On average, the heating rates as determined by Eq. 2, are calculated at $2-4 \mathrm{~K} \mathrm{day}^{-1}$, generally in line with other (uncertain) diabatic heating rates computed from several reanalyses (Ling and Zhang 2013). Horizontal mass transport from a heat source to a sink occurs in the upper isentropic layers with a return flow at the lower levels. Hence, the poleward transport occurs at higher values of $\theta$, while the equatorward transport in the zonal average is confined to the surface layers with $\theta$ below median surface potential temperature during cold air equatorward advection (Juckes et al. 1994; Held and Schneider 1999). Laliberte et al. (2012) showed that equatorward transport occurs throughout the troposphere but is the strongest at lower levels. The tilt of quasi-horizontal branches is due to some diabatic forcing of upward and downward mass transport during meridional exchange (TJ85), likely due to surface fluxes.

\subsection{Full meridional circulation}

The full isentropic circulation is thermally direct across all latitudes, and thus its direction is opposite to that of the Eulerian mean mass flux in the Ferrel cells. This implies that in the extratropics, the eddy mass flux dominates the mean flux associated with the Ferrel cells (Schneider 2006). However, downward motion is evident near $15-35^{\circ}$ latitude of each hemisphere above $310 \mathrm{~K}$, reflecting radiative cooling in the subtropics with peak rates of $1-2 \mathrm{~K} \mathrm{day}^{-1}$, consistent with those of Ling and Zhang (2013). The portion of the isentropic overturning circulation in the tropics is reminiscent of the $\mathrm{HC}$ in the isobaric coordinates (TJ85).

Table 1 Definitions of the seven MMC components

\begin{tabular}{llll}
\hline Name & Isentropic level & Circulation type & Description \\
\hline ITCZ & $320 \mathrm{~K}$ & Steady & Near-equatorial upward motion \\
NH HC & $320 \mathrm{~K}$ & Steady & Subtropical downward motion north of ITCZ \\
SH HC & $320 \mathrm{~K}$ & Steady & Subtropical downward motion south of ITCZ \\
NH transient updraft (NHTU) & $300 \mathrm{~K}$ & Transient & Subtropical upward motion in NH \\
SH transient updraft (SHTU) & $300 \mathrm{~K}$ & Transient & Subtropical upward motion in SH \\
NH transient downdraft (NHTD) & $285 \mathrm{~K}$ & Transient & Near-polar downward motion in NH. Use \\
& & & this level because not well defined in JJA \\
SH transient downdraft (NHTU) & $280 \mathrm{~K}$ & & at 280 K \\
\end{tabular}




\subsection{Steady and transient meridional circulation}

The annual-mean steady isentropic circulation, computed from monthly mean values as opposed to daily values, is similar to the isobaric circulation and reveals a direct HC in the low latitudes and an indirect Ferrel cell in the midlatitudes, particularly in the SH (Fig. 1c). In contrast, the annual-mean transient circulation depicts one strong overturning cell located in the extratropics and centred near $45^{\circ}$ latitude in each hemisphere (Fig. 1d). In the $\mathrm{NH}$, this heat source for the transient circulation can be primarily linked to the areas of warm oceanic currents off the east coast of the continents (TJ85).

As shown here, tropical and extratropical circulations are well separated in the dry isentropic view. Splitting the full circulation into steady and transient parts further isolates each of the circulation components, allowing for the analysis

(a) DJF

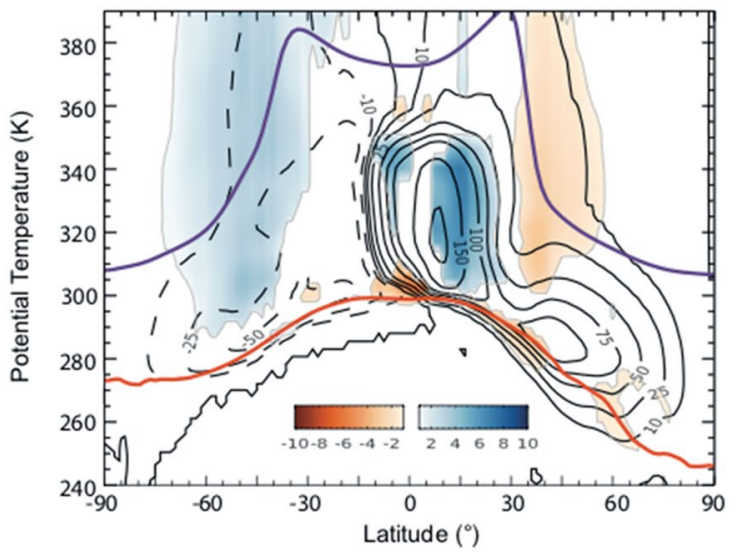

(c) JJA

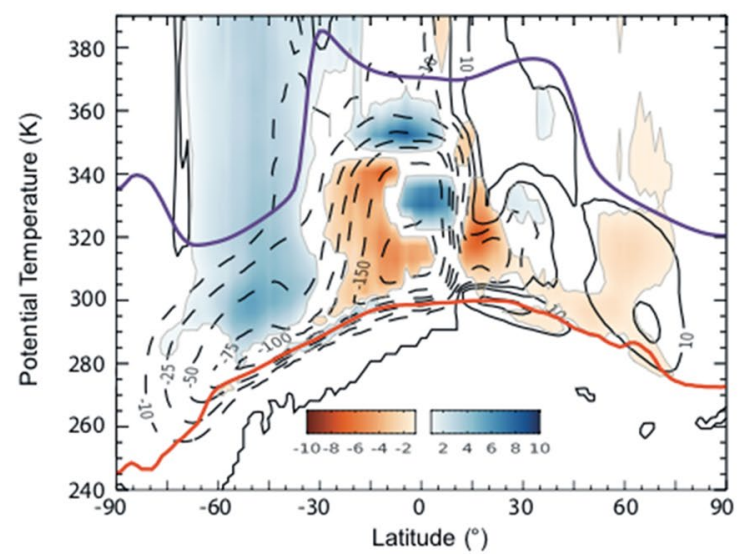

Fig. 3 Contours of seasonal means of the full isentropic streamfunction $\Psi\left(10^{9} \mathrm{~kg} \mathrm{~s}^{-1}\right)$ with negative (counterclockwise) contours dashed. Contour values as in Fig. 1. Shading represents linear trends in $\Psi$ $\left(10^{9} \mathrm{~kg} \mathrm{~s}^{-1}\right.$ decade $\left.^{-1}\right)$ from 1979-2017 that are statistically significant of variability in the upward and downward branches of the $\mathrm{HC}$ and midlatitude circulations.

\subsection{Seasonal cycle of meridional circulation}

\subsubsection{Full meridional circulation}

The seasonal evolution of the full circulation is displayed in Fig. 3. Consistent with the isobaric view (Dima and Wallace 2003), the tropical branches have a marked seasonal cycle building strength in local autumn, becoming better defined as the season progresses and the polar region cools, reaching its maximum (over $200 \times 10^{9} \mathrm{~kg} / \mathrm{s}$ ) during winter. During summer, the tropical circulation is much weaker, compared to other seasons. This suggests that there is relatively little net heating in the local summer (Fig. 3a). An important feature of the boreal summer (June-August, JJA) is a lobe of negative $\Psi$ in the SH low-mid-troposphere that extends well

(b) MAM

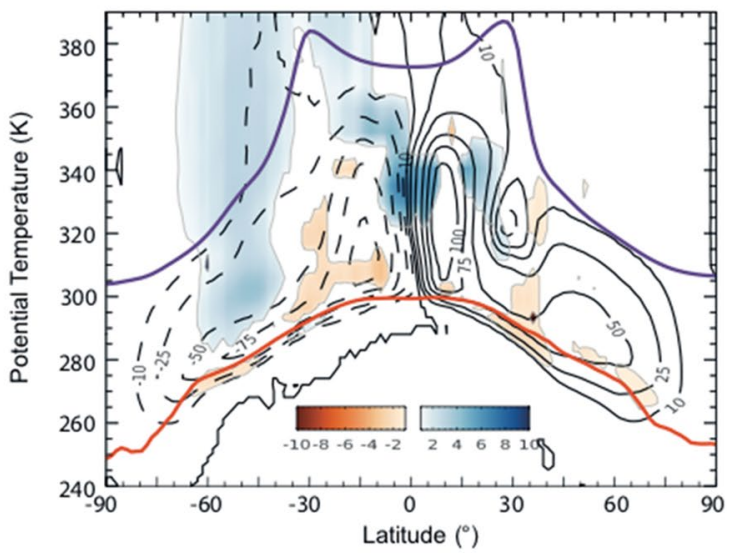

(d) SON

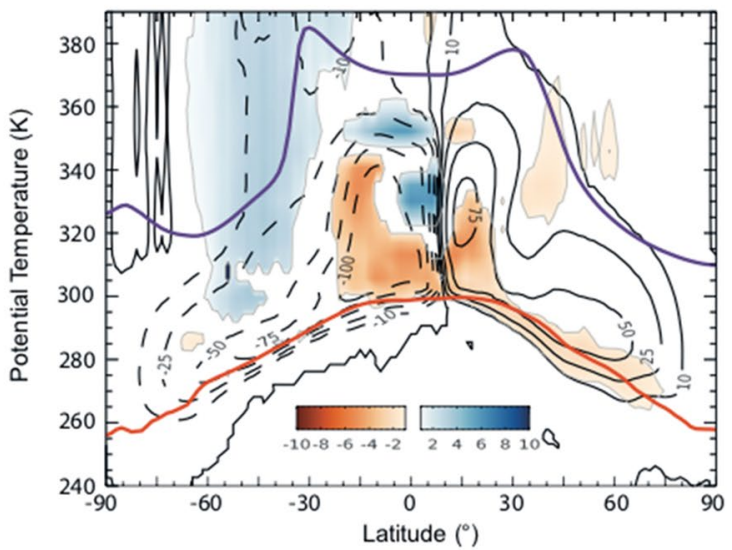

at the $90 \%$ level; thin grey lines enclose regions of significant trends. The purple and red lines represent the location of the average tropopause and the median surface potential temperature, respectively 
into the NH (Fig. 3c). This is hypothesized to be associated with the Asian monsoon-a phenomenon, which is known to displace the ITCZ closer to the NH subtropics (Chou and Chen 2010; Hoskins et al. 2020); while the low troposphere (below $300 \mathrm{~K}$ ) reflects the typical trade wind flow found over the cooler Pacific and Atlantic Oceans. The Asian monsoon, which dominates the zonal-mean low-level circulation during JJA, has a heat source over the Tibetan Plateau that corresponds to the upward motions around $30^{\circ} \mathrm{N}$ in the low and middle troposphere. The heat sink region, located over the south of Africa and Madagascar, intensifies the downward branch of the SH HC.

The extratropical circulations have their centres between 40 and $50^{\circ}$ latitude; although in the $\mathrm{NH}$ the circulation migrates further towards the pole during summer-a difference that may arise from a different land/sea ratio in the two hemispheres. The extratropical peak $\Psi$ is about one-half to two-thirds the magnitude of the $\mathrm{HC}$ in the same season. The seasonal cycle is similar to that in the tropics. The circulation is more persistent in the $\mathrm{SH}$.
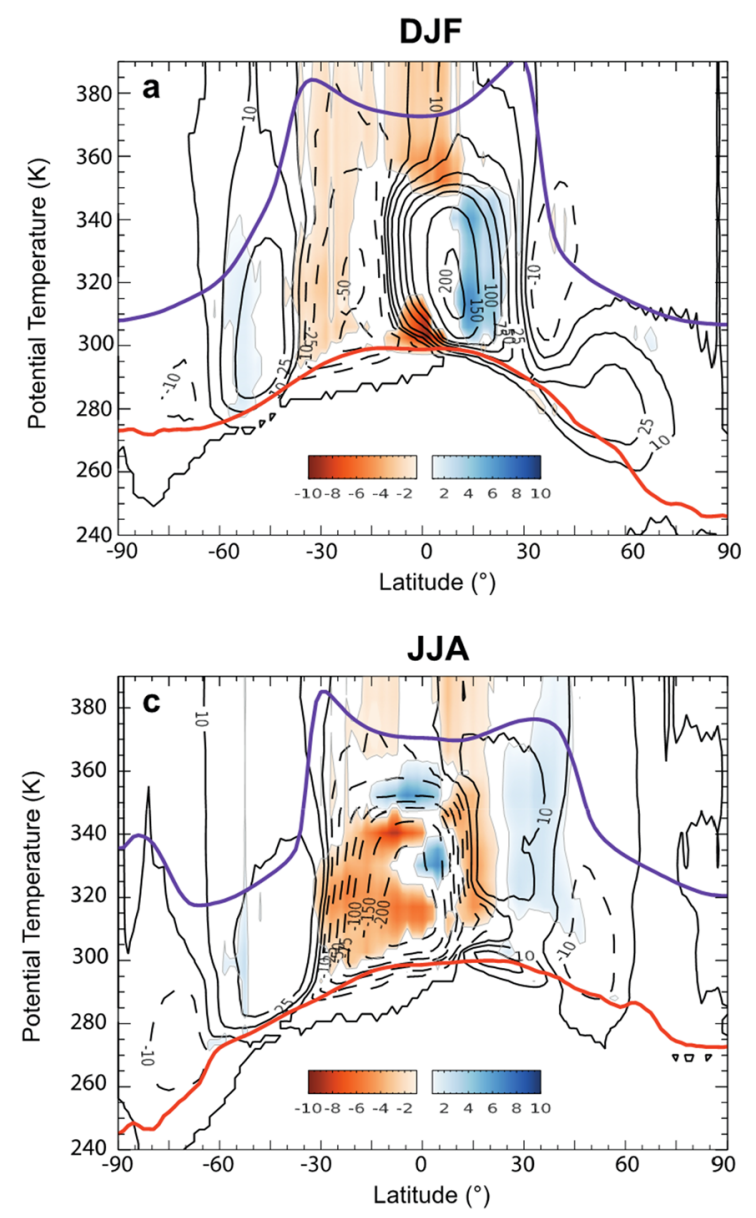

\subsubsection{Steady and transient meridional circulation}

The steady and transient circulations (Figs. 4 and 5) generally show seasonal cycles similar to the full circulation, with the strongest intensity during local winter and weakest during local summer. For the steady circulation (Fig. 4), a three-cell structure analogous to the isobaric circulation is observed in the $\mathrm{SH}$ during all seasons and in the NH during the equinoctial seasons, but not during the solstitial seasons. During boreal winter (DJF), the tropical and extratropical lobes of the steady isentropic circulation remain linked, with the Ferrel cell-like circulation elevated away from the surface (Fig. 4a), which can be explained by the winter monsoon with a rising branch over the Maritime Continent and a heat sink over Siberia. During boreal summer (JJA), a lobe of SH negative $\Psi$ extends into the $\mathrm{NH}$ and splits the expected $\mathrm{HC}$ into two parts, similar to what is observed in the full circulation. However, in the steady circulation, the extension is not as strong, suggesting that the eddy transport by monsoons and subtropical anticyclones plays an important role in that process.
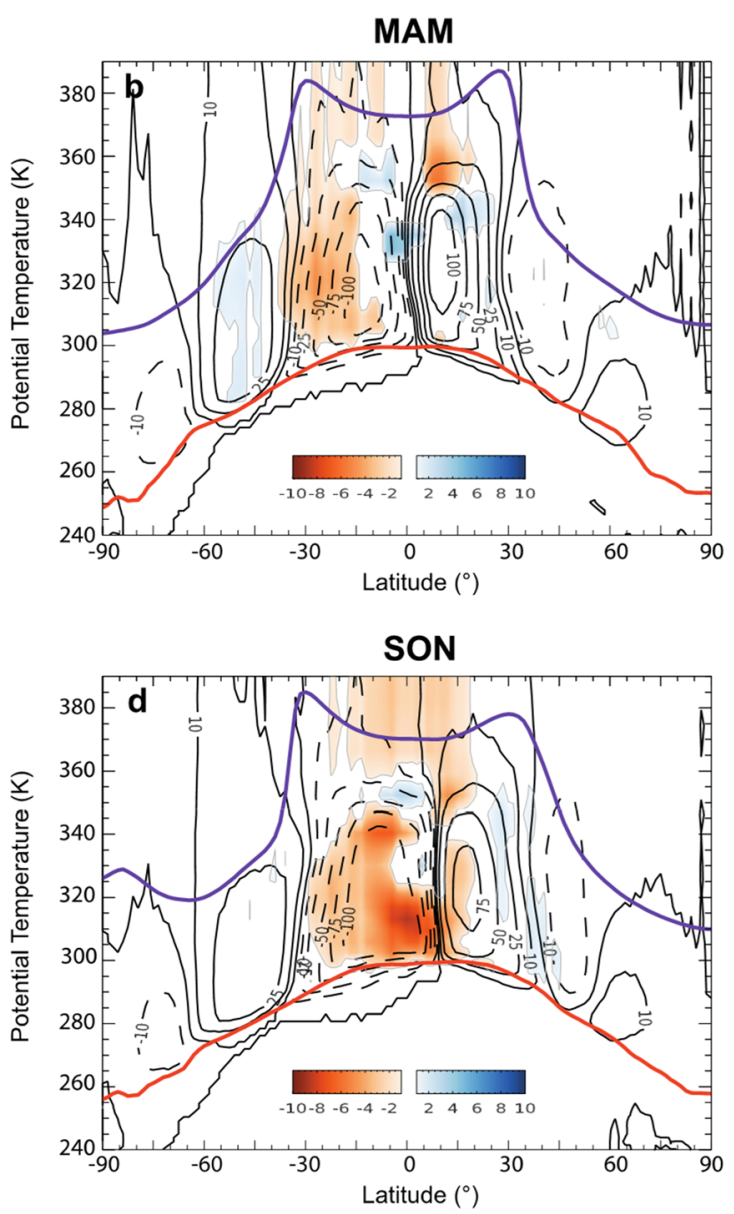

Fig. 4 As in Fig. 3, except for the steady component of $\Psi$ 

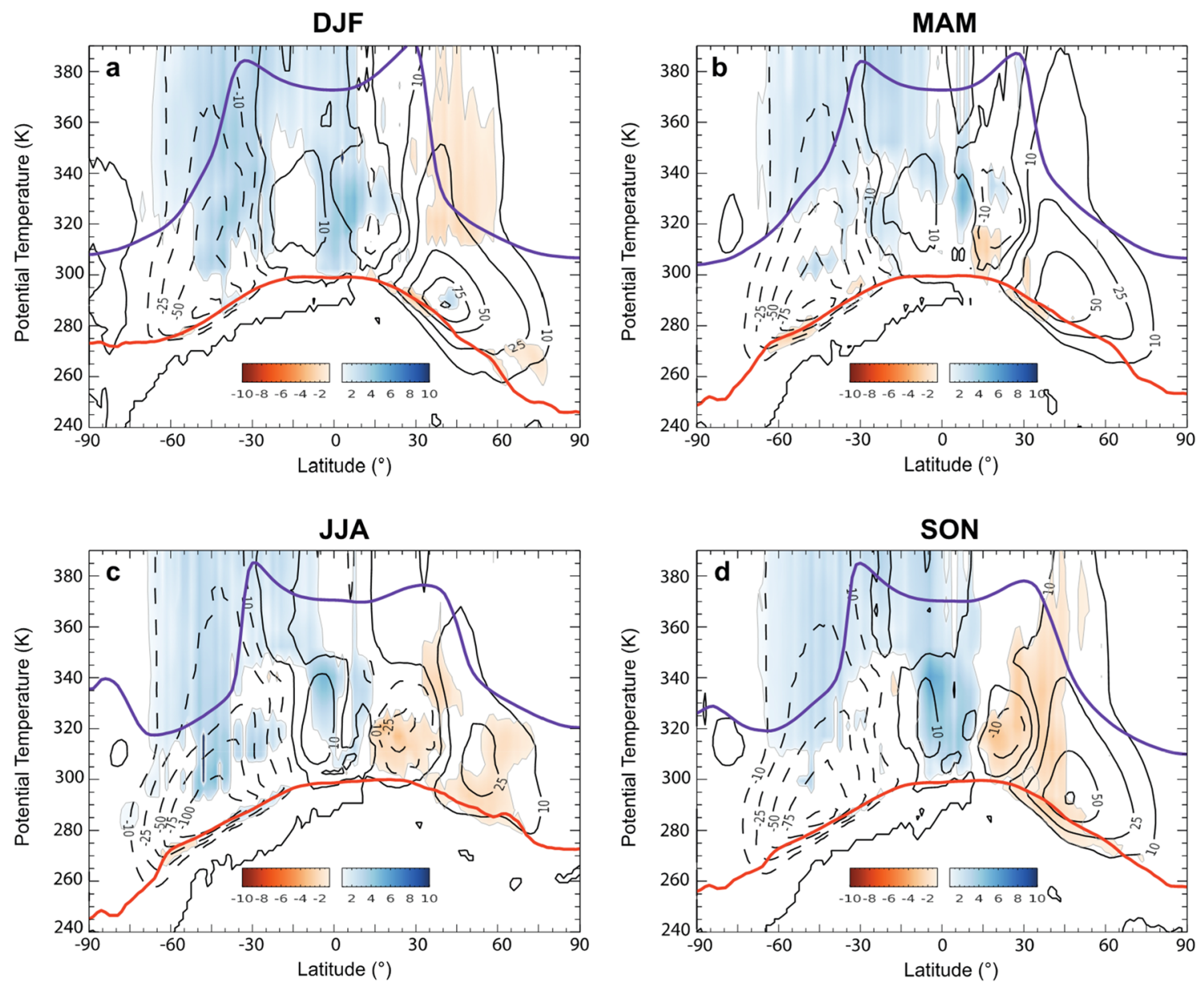

Fig. 5 As in Fig. 3, except for the transient component of $\Psi$

Fig. 6 Annual cycles of the intensity $\left(10^{9} \mathrm{~kg} \mathrm{~s}^{-1}\right)$ vs position (latitude) of the seven components of the global MMC. The ICTZ is shown in orange, $\mathrm{HC}$ edges in blue, upward and downward branches of the transient circulations in green and red, respectively. Note that branches are analysed at different isentropic levels where the mass transport is at its maximum $(320 \mathrm{~K}$ for ICTZ and HC edge, $300 \mathrm{~K}$ for transient up and $280 / 285 \mathrm{~K}$ for transient down in $\mathrm{SH} / \mathrm{NH}$, respectively)

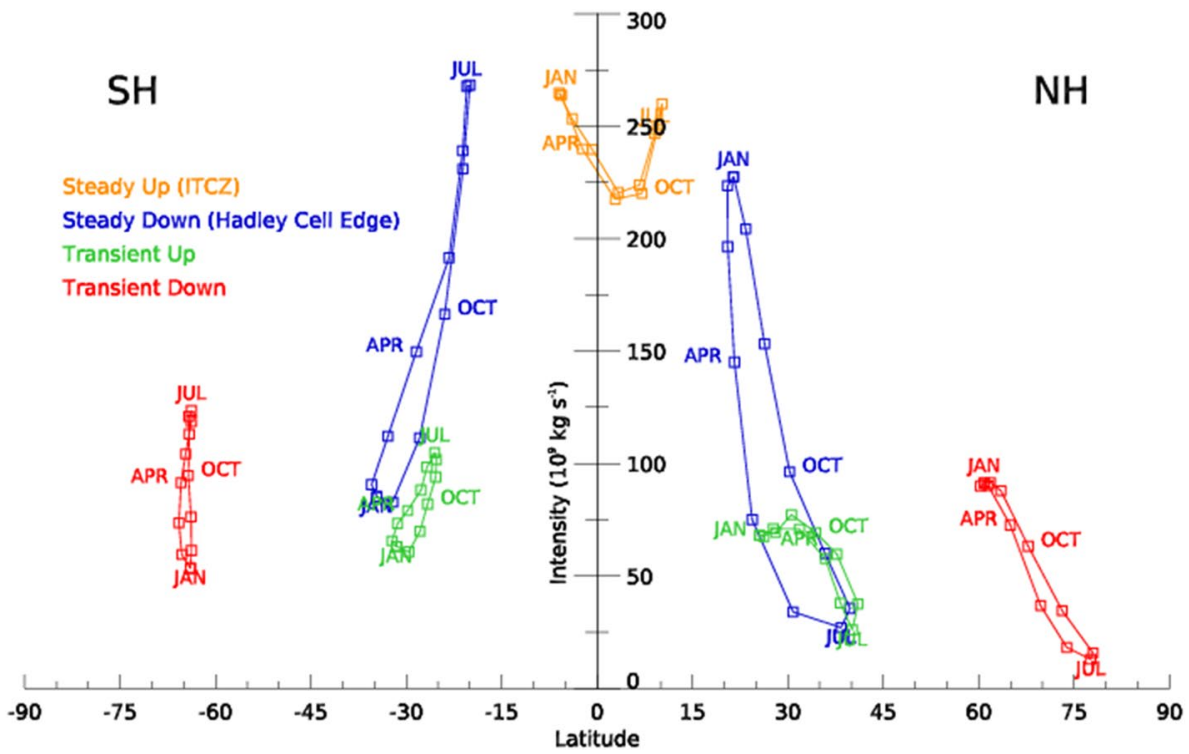


For the transient circulation (Fig. 5), significant lobes of $\Psi$ are observed in the midlatitude regions with the same sign as the prevailing circulation in the corresponding hemisphere (i.e., negative in the $\mathrm{SH}$, positive in the $\mathrm{NH}$ ), that are stronger in local winter and weaker in summer. In agreement with the results by TJ85 and Tanaka et al. (2004), there are weak thermally indirect transient cells in the tropics, that are 5-10 times weaker than the main cells in the extratropics.

\subsection{Seasonal cycle of the vertical MMC components}

The novel aspect of our work is the analysis of vertical branches of the atmospheric circulation, such as the ITCZ, the downward branch of the $\mathrm{HC}$, and the transient up- and downdraft, in isentropic coordinates. In this section we present the annual cycle of these circulation components (Fig. 6).

\subsubsection{ITCZ}

The location and intensity of the ITCZ is related to the strong heating associated with deep convective activity. In agreement with earlier studies using other metrics (Waliser and Gautier 1993; Kang and Lu 2012), the ITCZ (Fig. 6, orange) is found in the $\mathrm{NH}$ for most of the year, moving to the SH only from December through April. The total mass transport varies from about 220 to $270 \times 10^{9} \mathrm{~kg} \mathrm{~s}^{-1}$, being the strongest during the solstice seasons.

\subsubsection{HC downdraft}

The annual cycle of the $\mathrm{HC}$ extent is consistent with the isobaric view (Kang and Lu 2012; Nguyen et al. 2013). In the isentropic view, this branch is directly linked to the regions of radiative cooling in the subtropics. The intensity of $\mathrm{HC}$ downdraft has the largest seasonal cycle among all vertical branches (Fig. 6, blue). In their respective winters, the HC edge positions and intensities are located near $20^{\circ}$ with a total mass transport of $220-270 \times 10^{9} \mathrm{~kg} \mathrm{~s}^{-1}$, with the SH branch being more intense compared to its $\mathrm{NH}$ counterpart. In summer, both the poleward movement and weakening are more pronounced in the $\mathrm{NH}$. Importantly, the equatorward movement in the $\mathrm{HC}$ edges is larger than previously reported by Nguyen et al. (2013) using a more conventional metric when the isobaric meridional streamfunction changes sign. The difference indicates that the 'zero contour' does not necessarily coincide with the strongest radiative cooling.

\subsubsection{Transient updraft}

The transient updraft (Fig. 6, green) represents the rising portion of the extratropical overturning circulation. In the $\mathrm{SH}$, the updraft remains at around $30^{\circ} \mathrm{S}$ throughout the year. In the $\mathrm{NH}$, the circulation weakens considerably during the summer in addition to a significant poleward movement from $25^{\circ} \mathrm{N}$ in winter to $40^{\circ} \mathrm{N}$ in summer. During warmer months, the location of the transient updraft coincides with the downdrafts of the HC edge. During colder months, the transient circulation intensifies, but its upward branch is still 2-2.5 times weaker than the HC downdraft. This may be due to a large role of moisture in the extratropical mass transport, that would have been about twice as strong should the moist isentropic coordinates be used (Pauluis et al. 2010). Also note, that the $\mathrm{HC}$ and midlatitude branches are analysed at different $\theta$ levels, making a direct comparison of their relative locations more difficult.

\subsubsection{Transient downdraft}

The transient downdraft (Fig. 6, red) represents the cooling of air in high latitudes, which produces cold air masses that subsequently propagate equatorward. In the $\mathrm{SH}$, the transient downdraft is typically seen near $65^{\circ} \mathrm{S}$ all year round, with a modest seasonal cycle in intensity that strengthens in winter. The $\mathrm{NH}$ transient downdraft shows more variability, weakening and migrating from 60 to $75^{\circ} \mathrm{N}$ from winter to summer.

\section{Trends in the MMC}

\subsection{Trends in isentropic streamfunction}

Linear trends from 1979 to 2017 for each season for the full, steady and transient circulations are shown in Figs. 3,4,5. In terms of magnitude, trends are less than $10 \times 10^{9} \mathrm{~kg} \mathrm{~s}^{-1}$ decade $^{-1}$ everywhere. Depending on the sign of the background $\Psi$, this can indicate either strengthening or weakening.

\subsubsection{Trends in tropical circulation}

An intensifying trend is noted in the SH tropics (Fig. 3) in all seasons but DJF. This is primarily associated with the changing steady circulation (Fig. 4). For the NH HC, the trends are not as persistent across the seasons. During DJF, the HC shows a strengthening of the central portion and descending branch, associated with the steady circulation. During JJA the monsoon circulation has a negative trend, indicating an 
intensification in this case, with contributions from both the steady and transient flows (Figs. 4 and 5).

\subsubsection{Trends in the extratropical circulation}

Positive trends are observed in the SH between roughly 35 and $65^{\circ} \mathrm{S}$, extending vertically from $290 \mathrm{~K}$ into the stratosphere in all seasons and peaking in the mid- and upper troposphere (near $50^{\circ} \mathrm{S}$ and $300 \mathrm{~K}$ ) (Fig. 3). This indicates a reduction of the absolute value of $\Psi$ in the $\mathrm{SH}$. This trend is largely associated with the transient circulation (Fig. 5), with only a small amount present in the extratropical steady circulation (Fig. 4). An analogous feature located slightly higher in the troposphere and closer to the equator $\left(40^{\circ} \mathrm{N}\right)$ is observed in the $\mathrm{NH}$ during winter.

\subsubsection{Trends in the near-surface branch of the circulation}

The extratropical portions of the circulation show subtle but significant negative $\Psi$ trends in the near-surface layers of both hemispheres (Fig. 3). In the $\mathrm{NH}$, a weakening trend of the surface branch is observed in all seasons being most apparent in SON. In the $\mathrm{SH}$, an intensification of the surface branch of the flow between 45 and $60^{\circ} \mathrm{S}$ is observed in MAM. In both hemispheres, these near-surface changes are primarily associated with the transient circulation (Fig. 5).
The near-surface flow can be related to the trends in surface $\theta$ (Fig. S1). Positive trends in median surface $\theta$ across the $\mathrm{NH}$, becoming much stronger near the pole, north of $60^{\circ} \mathrm{N}$, are a reflection of the 'Arctic amplification' of the global warming (Serreze and Barry 2011; Cohen et al. 2014; Coumou et al. 2014). The Arctic amplification has led to a weakening of the equator to pole temperature gradient and, hence, a reduction in the relative strength of the near-surface flow (consistent with Fig. 3). In contrast, the pattern in the $\mathrm{SH}$ reveals a region of significant cooling between roughly $50^{\circ} \mathrm{S}$ and $70^{\circ} \mathrm{S}$, that is most pronounced during MAM. This pattern is likely related to the circumpolar upwelling and equatorial heat transport within the Southern Ocean (SO), shown by Armour et al. (2016). Kostov et al. (2017) found that the surface cooling in the SO is a fast response to the increasing positive trend in the Southern Annular Mode (SAM), observed in the recent decades. This is in agreement with the intensifying near-surface MMC branch in the SH.

\subsection{Trends in the vertical MMC components}

Seasonal linear trends in the position and intensity of the vertical branches are shown in Fig. 7. We also show time series for the downward branch of the $\mathrm{HC}$ and the transient updraft in Figs. 8 and 9 as they reveal some important step changes; the time series for other branches can be found in the Supplemental information (Figs. S2, S3).
Fig. 7 Seasonal trends in the a position $\left({ }^{\circ}\right.$ latitude decade $\left.{ }^{-1}\right)$ and $\mathbf{b}$ intensity $\left(10^{9} \mathrm{~kg} \mathrm{~s}^{-1}\right.$ decade $\left.^{-1}\right)$ of the vertical branches of the meridional circulation. Positive (negative) trend in intensity indicates an intensification (weakening) of the branch (either upward or downward). Larger symbols with/without black edges indicate statistical significance at 95/90\% level and colours are for each season
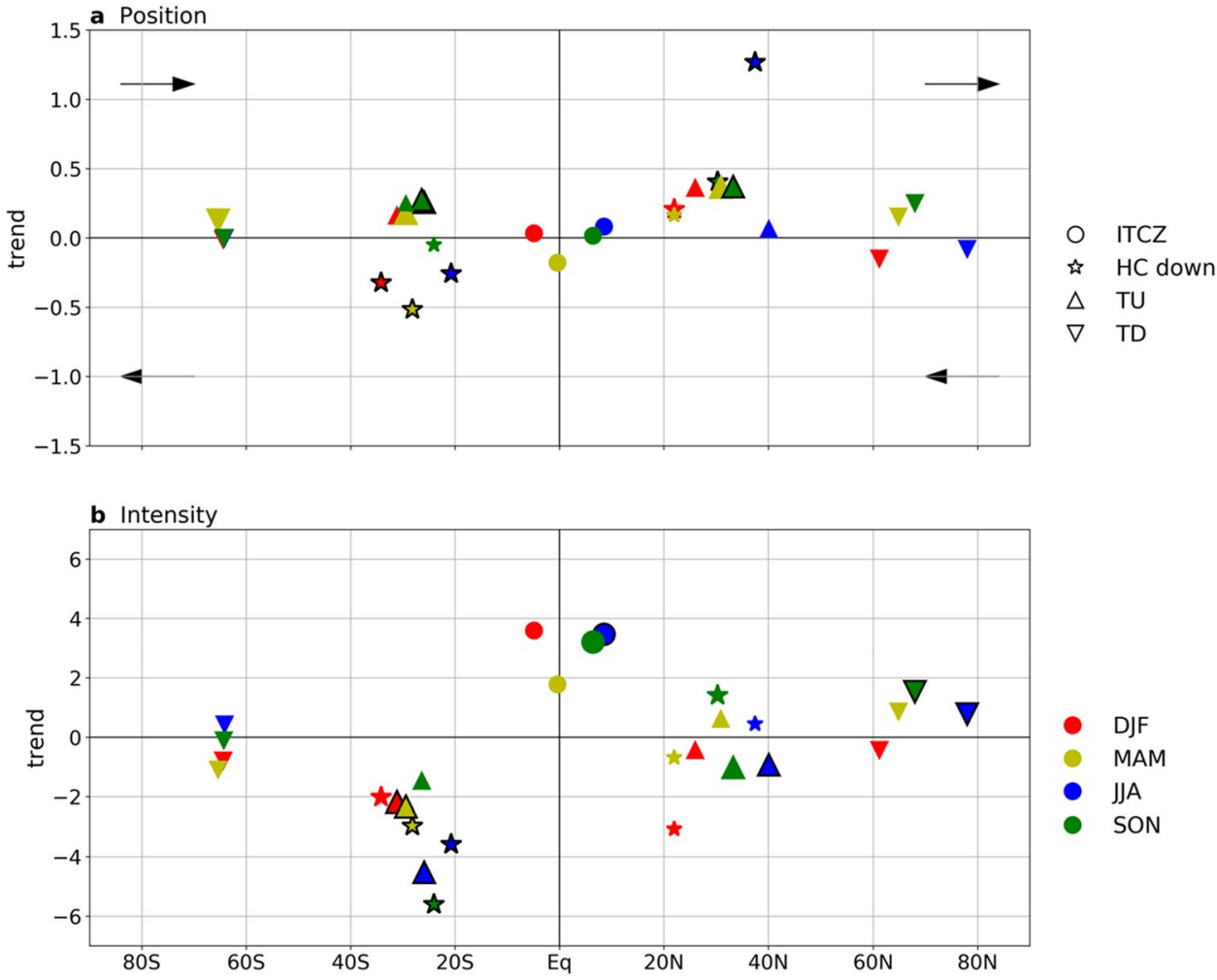


\section{(a) NH HC Position}

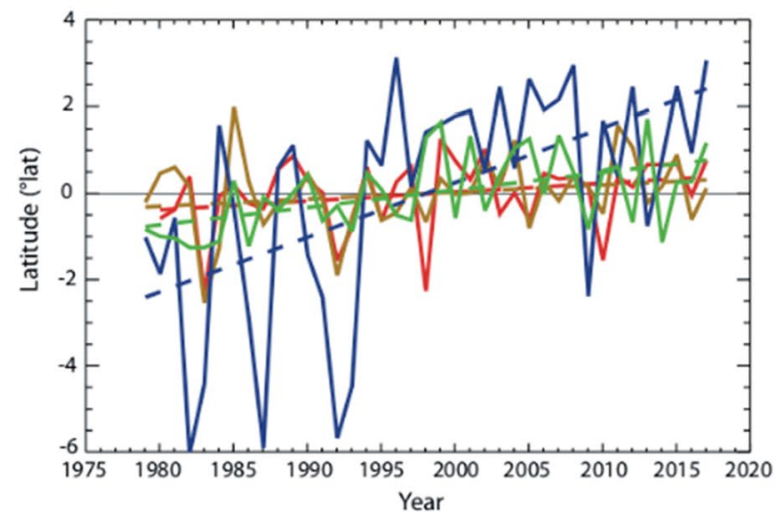

(c) SH HC Position

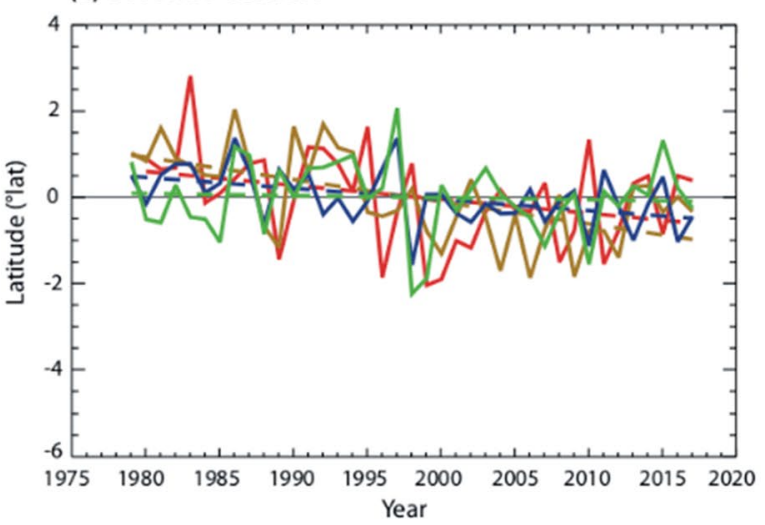

Fig. 8 Time series showing the seasonal anomaly of characteristics of $\mathrm{HC}$ edges a $\mathrm{NH}$ position (degrees latitude), b $\mathrm{NH}$ mass transport (intensity: $10^{9} \mathrm{~kg} \mathrm{~s}^{-1}$ ), $\mathbf{c ~ S H}$ position and $\mathbf{d ~ S H}$ mass transport. Anomalies are calculated relative to the mean of each respective sea-

\subsubsection{ITCZ}

The ITCZ shows no statistically significant trends in position (Figs. 7a, S2a). The trends in total mass transport within the ITCZ (Figs. 7b, S2b) are positive, reaching $3.44^{\circ}$ decade $^{-1}$ significant at $95 \%$ level in JJA. This suggests a tendency towards increased latent heating associated with enhanced deep convection there, consistent with results found on changes of the ITCZ using more sophisticated methods (Byrne et al. 2018).

\subsubsection{HC downdraft}

For the downward branches of the HC, the tendency is towards poleward movement in both hemispheres (Figs. 7, 8). In the SH, statistically significant tropical expansion is observed during all seasons except spring. Where significant, the rate of expansion varies between 0.26 and $0.51^{\circ}$ decade $^{-1}$, in line with previous studies (Lucas et al. 2014; (b) NH HC Mass Transport

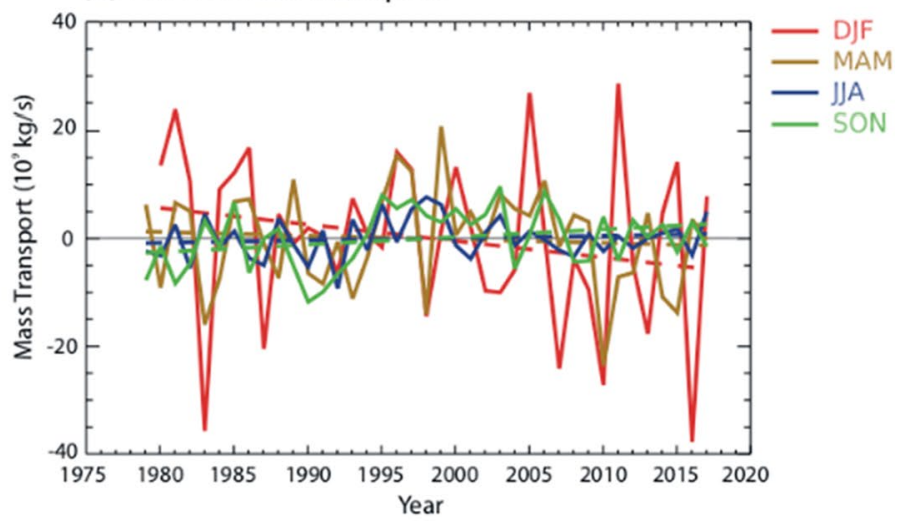

(d) SH HC Mass Transport

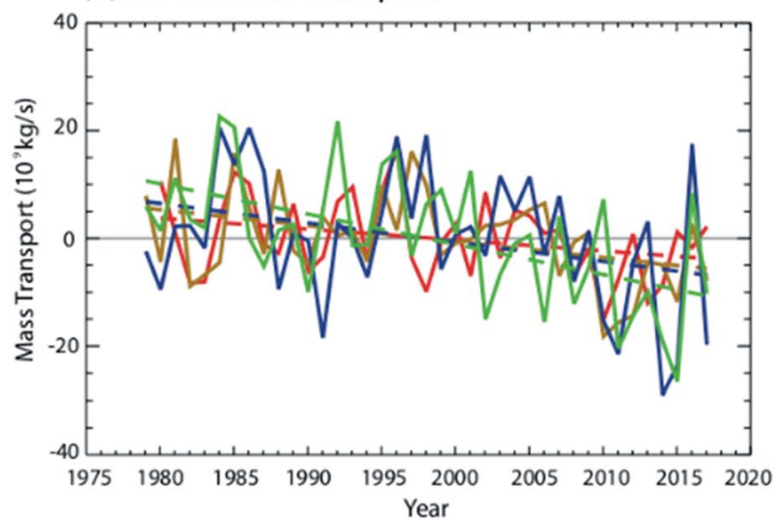

son: (red) DJF, (brown) MAM, (blue) JJA and (green) SON. Dashed lines represent linear regression trend lines. Negative values mean stronger mass transport

Staten et al. 2020). Intensification of the mass transport is statistically significant in all seasons (Figs. 7b, 8d). Trends in SON are particularly strong $\left(-5.60 \times 10^{-9} \mathrm{~kg} \mathrm{~s}^{-1}\right.$ decade $\left.^{-1}\right)$, despite there being no change in position.

For the NH HC, trends also show expansion in all seasons (Figs. 7a, 8a), but only reach statistical significance during boreal summer and autumn. Summer trends are particularly strong, in excess of $1.2^{\circ}$ decade $^{-1}$. Rather than a gradual trend during this season, the time series shows sharp changes in the position of the HC edge. Before 1993, the HC edge metric (Fig. 8a) switches between roughly $32^{\circ} \mathrm{N}$ and $38^{\circ} \mathrm{N}$; after 1993 the location becomes more persistent around $38^{\circ} \mathrm{N}$ with a slower trend. The total mass transport in the $\mathrm{NH}$ shows trends with a mixed sign (Figs. 7b, 8b), although only the SON positive trend is statistically significant. The strong but insignificant negative trend in winter is due to considerable interannual variability in the time series (Fig. 8b), with the negative peaks clearly coinciding with El Niño years. 
(a) NHTU Position

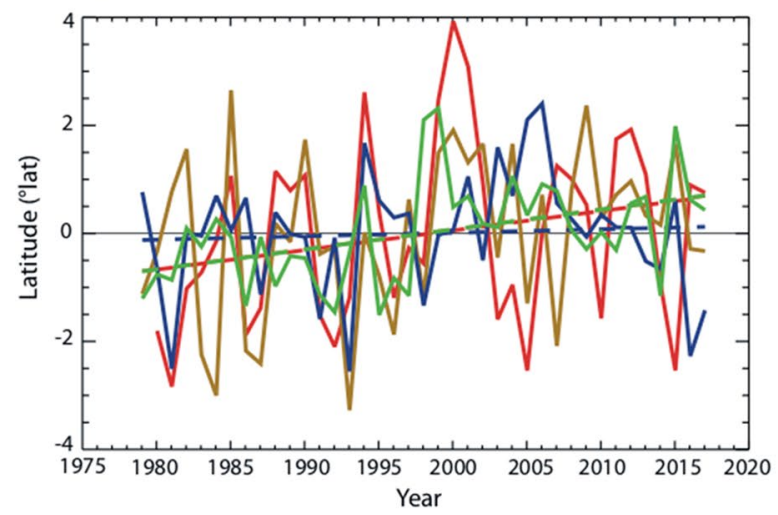

(c) SHTU Position

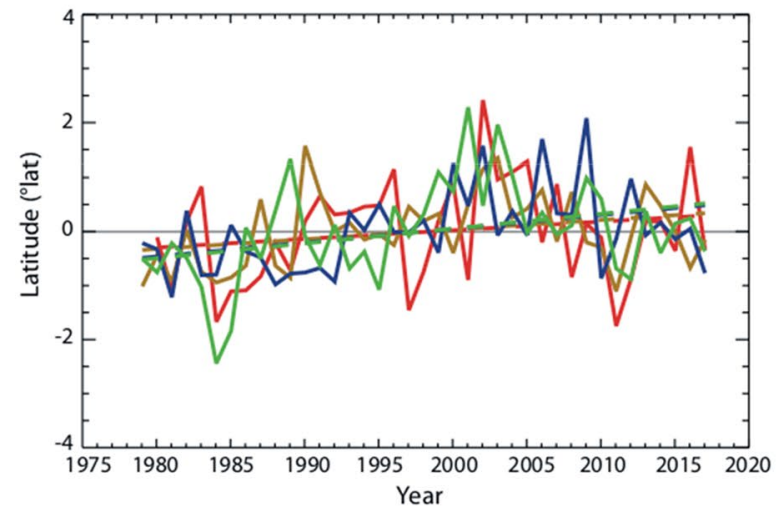

(b) NH TU Mass Transport

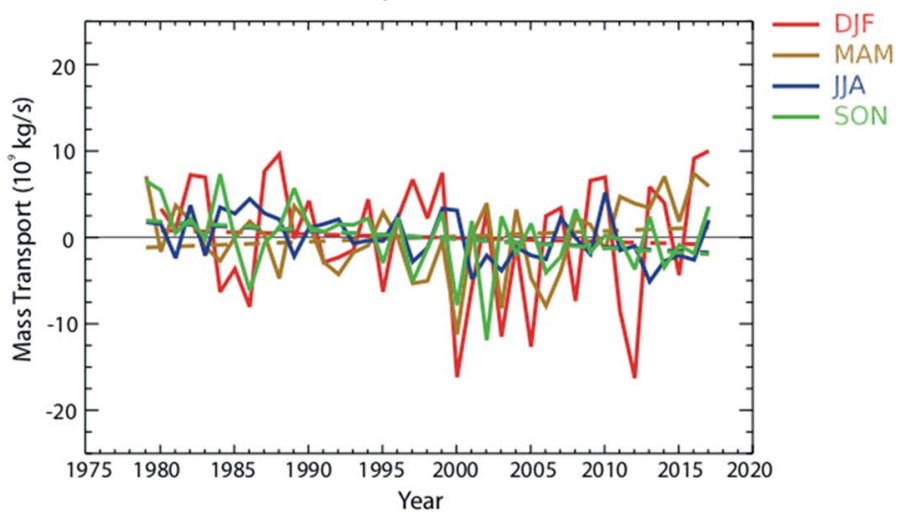

(d) SH TU Mass Transport

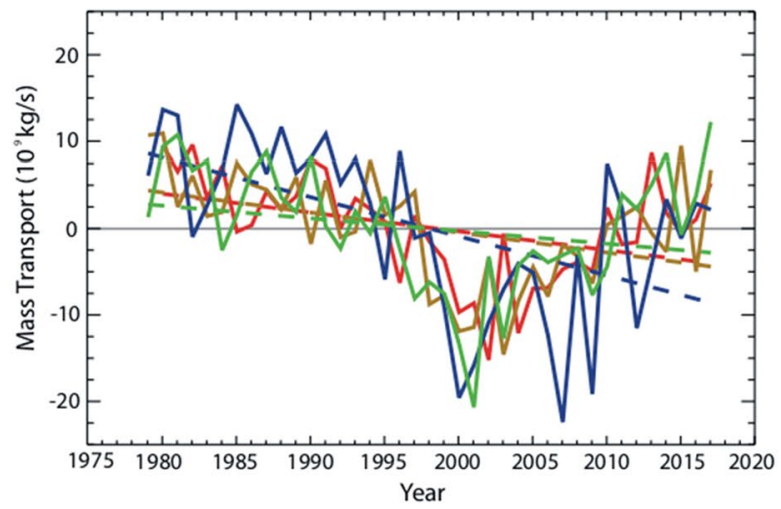

Fig. 9 As in Fig. 8, expect for the characteristics of the transient updraft (TU): a its NH position, b NH mass transport, $\mathbf{c}$ SH position and d SH mass transport. Positive values mean stronger mass transport

\subsubsection{Transient updraft}

The transient updraft shows considerably different behaviour between the two hemispheres (Figs. 7, 9). In the SH, equatorward and weakening trends are observed in all seasons, with the largest change in position in JJA and SON $\left(0.26\right.$ and $0.28^{\circ}$ decade $\left.^{-1}\right)$ and the largest weakening in JJA $\left(-4.53 \times 10^{9} \mathrm{~kg} \mathrm{~s}^{-1}\right.$ decade $\left.^{-1}\right)$.

The interannual behaviour of the SH transient updraft is more complex than what is suggested by the linear trend estimates in Fig. 7b. Although the overall trend of the mass transport is negative, there is considerable decadal variability in that metric during all seasons (Fig. 9d). From the start of the period until the late-1990s, the mass transport shows little trend. From 1997/8 until about 2002, the mass transport demonstrates an abrupt, strong decline (by up to $2 \times 10^{10} \mathrm{~kg} \mathrm{~s}^{-1}$ ), followed by a gradual recovery to near its original value by 2010 .

In the $\mathrm{NH}$, poleward and weakening trend dominates with statistical significant values for MAM and SON movement $\left(0.37^{\circ}\right.$ decade $^{-1}$ in both seasons $)$ and JJA and SON weakening $\left(-0.93\right.$ and $-1.03 \times 10^{10} \mathrm{~kg} \mathrm{~s}^{-1}$, respectively).

\subsubsection{Transient downdraft}

The SH transient downdraft shows no statistically significant movement. Between 1998 and 2010, there is evidence of weakening (Fig. S3d), in agreement with the observed weakening of the updraft (Fig. 9d), although not as prominent.

The NH transient downdraft also shows no significant movement trends (Fig. 7a) but marked interannual variability (Fig. S3a) and weakening trends statistically significant during JJA and SON $\left(0.78\right.$ and $1.53 \times 10^{10} \mathrm{~kg} \mathrm{~s}^{-1}$, respectively).

\section{Discussion}

The analysis of the dry isentropic circulation details a picture of an evolving MMC over 39 years. A poleward expansion of the $\mathrm{HC}$ is observed although not uniformly across the seasons. Overall, the changes are largest in the $\mathrm{SH}$, but the greatest rate of expansion occurs in the NH during JJA. 
Accompanying this change is an intensification of the downward branch of the $\mathrm{HC}$; this is more strongly observed in the SH. In the SH extratropics, strong variability is associated with the polar front, with a reduction in strength of the vertical components of the transient circulation during the early twenty-first century. A sharp transition in the $\mathrm{SH}$ HC position and transient circulation is noted in the late1990s. These abrupt changes could well be indicative of major global changes; however, the caveats of the data and methods must be considered. While a detailed analysis on the relationship of the MMC in isentropic view with largescale modes of variability is outside the scope of this paper, we discuss possible drivers in the remainder of the section to lay the foundation for future research.

\subsection{Tropical expansion}

The wide variety of metrics in the literature measure slightly different things, requiring careful interpretation of the results (Waugh et al. 2018; Staten et al. 2020). In this study, tropical expansion is measured with a unique metric that is specific to the isentropic calculation. The $\mathrm{HC}$ metric considered here is based in the mid-troposphere and the results show a similarity with other reanalysis-based studies using the widely used 'PSI500' metric (i.e. the subtropical latitude where the zonal-mean meridional mass streamfunction at $500 \mathrm{hPa}$ changes sign; Grise and Davis 2020).

The results here suggest that the strongest seasonal tropical expansion (outside of the NH JJA signal that is discussed later) occurs in the local autumn. This is in good agreement with Staten et al. (2018). However, the time series plots of $\mathrm{HC}$ edge position show more complex behaviour than that expected from a simple linear trend (Fig. $8 \mathrm{a}$ and c). In many seasons, the maximum poleward extent of the HC edge occurs in the late-1990s, with a period of rapid expansion prior to the peak, followed by neutral expansion or even slight contraction. This behaviour has been hypothesized to be related to the phase of the Pacific Decadal Oscillation (PDO) or equivalently the Interdecadal Pacific Oscillation (IPO) (Grassi et al. 2012; Allen et al. 2014; Quan et al. 2014; Lucas and Nguyen 2015; Amaya et al. 2017; Grise et al. 2018, 2019; Staten et al. 2020). Furthermore, a combination of GHG and ozone forcing might be important in the SH; however, to date, in the $\mathrm{NH}$ a clear anthropogenic signal has not yet emerged (Amaya et al. 2017; Grise et al. 2019; Grise and Davis 2020). It is worth noting that in model simulations under a $\mathrm{CO}_{2}$ forcing the anthropogenic signal in the $\mathrm{NH}$ is detectable and expected to be the largest during boreal autumn (Watt-Meyer et al. 2019).

The greatest HC expansion $\left(1.26 \pm 0.74^{\circ} \mathrm{decade}^{-1}\right)$ occurs during the NH summer (JJA), when the overturning cell is very weak and is not defined nearer to the surface due to the influence of the Asian monsoon. However, the time series (a) Volcanic JJA steady composite

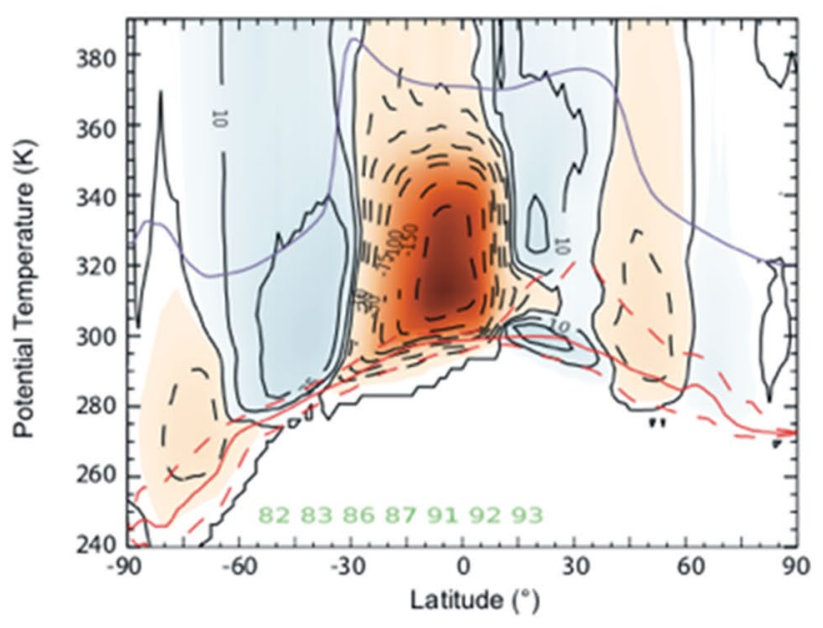

(b) Non-volcanic JJA steady composite

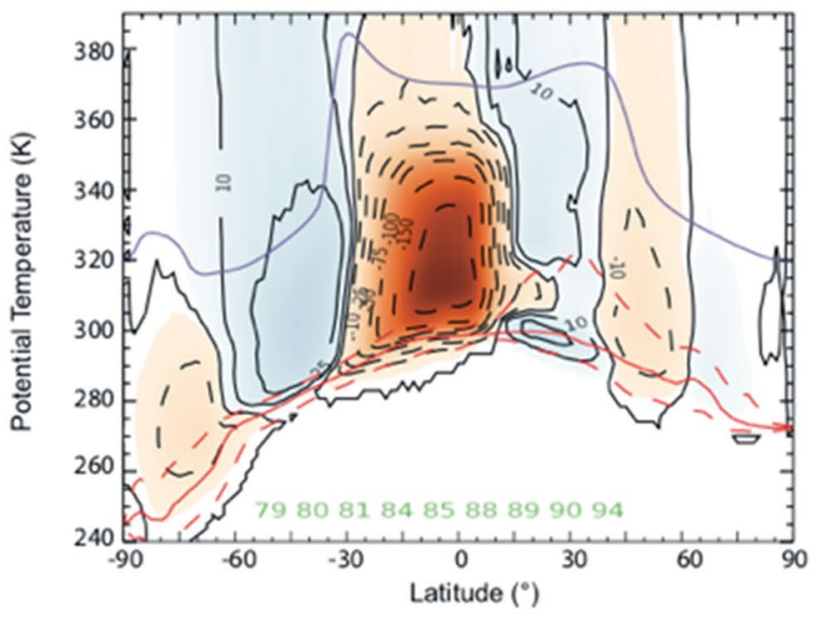

(c) Composite VMT (320 K)

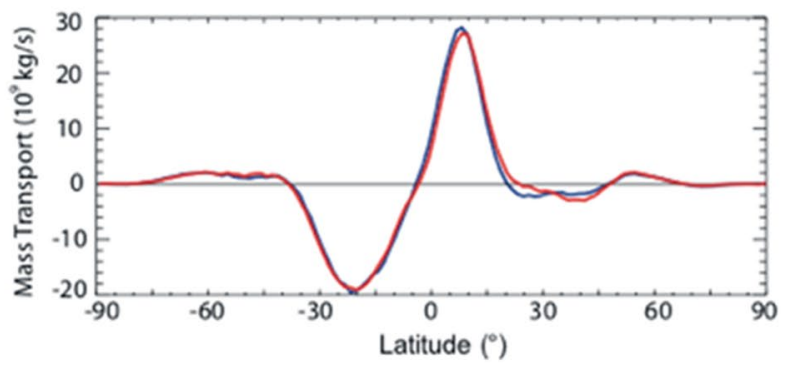

Fig. 10 Composite steady $\Psi$ for pre-1994 a volcanic and b non-volcanic years. Specific years are annotated in green on these panels. Contours are as in Fig. 1. c Composite VMT profiles at $320 \mathrm{~K}$ for (blue) volcanic and (red) non-volcanic composite plots

of the $\mathrm{HC}$ edge reveals that this rate of expansion is strongly driven by a series of the NH HC contractions early in the record (1982-3, 1986-7 and 1991-3; Fig. 10a). While these years correspond to strong El Niño events, ENSO has little 
apparent impact on the position of the NH HC edge from the mid-90s, possibly due to a shift to more central Pacific-type El Niño events (Freund et al. 2019).

Our results suggest that these contractions might also result from volcanic eruptions and their impact on the upper troposphere/lower stratosphere. Indeed, the eruptions of El Chichón (April 1982) and Mt Pinatubo (June 1991), both well known for their global climate impacts (Robock 2000), preceded two of the three periods when the HC edge was displaced equatorward during JJA. The third period occurred after the less well-known eruption of Nevado del Ruiz in Colombia during November 1985 (Naranjo et al. 1986; Krueger et al. 1990). Historical records of stratospheric aerosol optical depth show a significant but short-lived increase in the deep tropics because of this eruption (Vernier et al. 2011; Thomason et al. 2018). Composite plots (Fig. 10) for pre-1994 volcanic and non-volcanic periods identify changes to the steady $\Psi$ around $320 \mathrm{~K}$ at $30^{\circ} \mathrm{N}$, a region identified as a source of stratosphere-troposphere exchange ( ̌́kerlak et al. $2014,2015)$. These changes are most visible in JJA because of the weak nature of the $\mathrm{NH}$ tropical circulation during that season; during other seasons, the volcanic signal is likely too small to identify against the stronger background flow. Pausata et al. (2020) suggests a mechanism of equatorward $\mathrm{NH} \mathrm{HC}$ contractions following tropical volcanic eruptions in the NH. These eruptions lead to an asymmetric hemispheric cooling, which displaces the ITCZ towards the equator, leading to an El Niño-like response 4 to 6 months later.

As the high rate of tropical expansion during JJA in the NH since 1979 appears to have been influenced by the high range of natural variability (consistent with Grise et al. $(2018,2019))$, we conclude that the observed trend in the $\mathrm{NH} \mathrm{HC}$ during boreal summer is likely an artefact of the choice of start time of the calculation.

\subsection{Intensification of the HC}

The results in this paper also suggest changes to the strength, or intensity, of the $\mathrm{HC}$, that are significant at least at the $90 \%$ level in all seasons in the $\mathrm{SH}$. The intensification of the $\mathrm{SH}$ $\mathrm{HC}$ does not align with some theoretical studies that suggest that its magnitude should weaken in a warming climate (Held and Soden 2006; Chemke and Polvani 2019). However, D'Agostino et al. (2017) report that approximately half of the models they examined show a strengthening of the $\mathrm{SH}$ $\mathrm{HC}$ with warming temperatures.

The physical reason for why the SH HC may be intensifying are unclear. Here, we discuss several hypotheses that may explain the observed behaviour. These are:

1. Changes to the strength of the meridional temperature gradient (Seo et al. 2014). In the SH, the overall meridional $\theta$ gradient has been strengthening between the equator and the Southern Ocean (see Fig. S1). This is consistent with the intensification of the SH HC. In the $\mathrm{NH}$, meridional temperature gradient is weakening, with strong warming near the pole. This is different to the behavior of the NH HC, which shows a modest (insignificant) trend towards intensification in DJF and no trend in other seasons.

2. Compensation of the increasing ITCZ precipitation (and, hence, heating) by the downward branch of the HC. The upward mass transport within the ITCZ branch has increased in most seasons, although not statistically significant in DJF and MAM. Heating in this region is primarily driven by the release of latent heat associated with precipitation, that has increased in the recent years (Wodzicki and Rapp 2016). This may explain increased mass transport in the SH HC downdraft, while the downward branch of the NH HC is strongly affected by the summer monsoon, masking a possible relationship of the HC edge with the ITCZ.

3. A response to aerosols, as aerosols affect the climate in complex ways, including direct, semi-direct and indirect effects. Published results using general circulation models (GCMs) are quite sensitive to how aerosols are treated, and which processes are included (Choi et al. 2019). Because aerosol concentrations are non-uniform - there is stronger aerosol forcing in the $\mathrm{NH}$ - the response can differ between the hemispheres. Moreover, model experiments with different aerosol parametrisations have shown contrasting results (Chemke and Dagan 2018; Rotstayn and Lohmann 2002; Ming and Ramaswami 2011), making it difficult to attribute SH changes to the aerosols. Aerosol may also affect SST and so drive changes to the tropical circulation (Allen et al. 2014).

Although each of these hypotheses has the potential to explain the intensification of the SH HC identified in this study, it is likely that some combination of these factors and/ or their interactions has more explanatory power. Natural variability, like that driven by ENSO or other decadal variability (Lucas and Nguyen 2015), would have also played a role.

\subsection{SH transient circulation}

The behaviour of the SH transient circulation clearly shows decadal-scale variability that is not present in the $\mathrm{NH}$; this variability is observed in both the transient updraft and downdraft portions of the circulation (see Figs. 9d, S3). Composite analyses of the circulation are compared for two austral winter periods: the 'high VMT' period comprising 1979-1994, 2010-2011 and 2014 and the 'low VMT' periods, running from 1997 to 2009 with 2012-2013 (Fig. 11). 

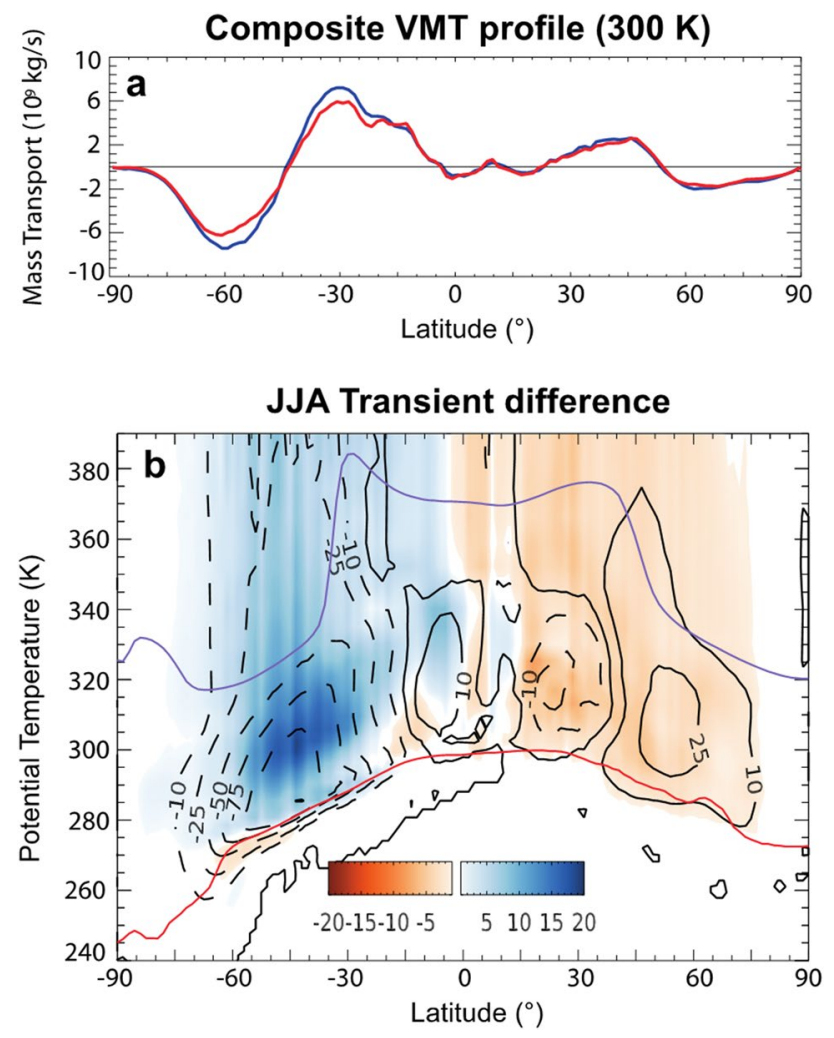

Fig. 11 a Composite VMT profiles at $300 \mathrm{~K}$ for (blue) high-VMT years $(1979-1994,2010-11,2014)$ and (red) low-VMT years (19972009, 2012-13). b Contours are the transient composite for the highVMT years, with contours as in Fig. 1, while shading represents the difference in transient $\Psi$ between low-VMT and high-VMT years. Values and sign given by inset legend. See text for further discussion

During the low-VMT period, the magnitude of vertical mass transport in the transient updraft and downdraft is reduced by $15 \%$ on average. The change in the transient updraft is centred at $30^{\circ} \mathrm{S}$, with the change in the transient downdraft identified near $60^{\circ} \mathrm{S}$ (Fig. 11a). Differences in the transient $\Psi$ between the two periods (Fig. 11b) show the largest weakening in the mid- and upper troposphere (290-310 K), extending into the lower-stratosphere in the subtropics and mid-latitudes. In the SH transient flow, this pattern 'flattens' the streamlines, suggesting that the poleward transport in the transient circulation has a stronger adiabatic component during 'low VMT'.

Decadal changes in the global evolution of precipitation, temperature and global circulation have been linked to lowfrequency changes in the Pacific SST such as the IPO or PDO (Fyfe et al. 2013; Meehl et al. 2013; Trenberth and Fasullo 2013; England et al. 2014; Huber and Knutti 2014; Kosaka and Xie 2016; Liu et al. 2016). The changes to the SH transient circulation observed in this work are consistent with the switch of the IPO in the late 1990s from its warm to cold phase, at least in terms of timing (Henley et al. 2015). Wills et al. (2018) use 'low frequency component analysis' that filters out the canonical ENSO signal and further separate different components of the Pacific long-term SST variability, such as a long-term global warming signal, an aerosol-forced warming mode similar to La Niña, a central equatorial Pacific mode and the PDO. They show a strong central equatorial Pacific low-frequency mode in the SH subtropical Pacific centred at $30^{\circ} \mathrm{S}$ and $155^{\circ} \mathrm{W}$ (Fig. $4 \mathrm{c}$ in Wills et al. 2018). This pattern changes to a negative phase in the late-1990s, indicating warming in the subtropical Pacific in the $\mathrm{SH}$, and appears to return to its positive phase in 2013/14, providing a possible explanation for the variability in the SH transient circulation (Fig. 9d). As the central equatorial Pacific low-frequency mode is shifted to the $\mathrm{SH}$, it becomes clearer why the $\mathrm{NH}$ transient circulation does not show similar multidecadal variability, which would be expected should the IPO be the leading driver of the lowfrequency variability.

\subsection{Should we trust the results?}

One potential limitation of this study lies in uncertainty surrounding the reanalysis product, the ERA-I in this case. While the reanalysis model features and physics are kept fixed, the observing system whose data are assimilated into the model is constantly changing. The space-borne observation system in particular, with new and improved instrumentation, is constantly evolving. These changes can lead to inhomogeneities in the reanalysis data and reduce their reliability for measuring climate trends, though most studies agree that changes are quite modest (e.g., Bengtsson 2004; Thorne and Vose 2010; Lucas et al. 2012; Simmons et al. 2014; Loeb et al. 2014; D’Agostino and Lionello 2017).

Besides inhomogeneities, there are some other known problems with reanalyses. For example, Davis and Davis (2018) suggested that mass was not conserved in reanalysis products, particularly in the earlier generations primarily affecting the position trend of the $\mathrm{HC}$ edge. Their results suggest that ERA-I was not as severely affected by this change. Chemke and Polvani (2019) found that misrepresentation of precipitation in reanalyses had caused errors in latent heating that affected the intensity of the NH HC during DJF. Chen et al. (2020) compared the atmospheric circulation in the isentropic coordinates in ERA-I and its successor, ERA5 (Hersbach et al. 2020). They reported that ERA5 reveals much stronger overturning circulation in the tropics compared to ERA-I due to mesoscale processes that are better resolved in the new dataset. On the other hand, Hersbach et al. (2020) found large cold biases in the lower stratosphere in ERA5 but not in ERA-I - this level is important for accurately representing the overturning circulation. The above discussion suggests that use of the ERA-I (or any other reanalysis) data to examine changes may be problematic, and 
that the abrupt changes, identified herein, may be confused by changes in the data assimilated through time.

Despite these potential data flaws, observational studies have noted 'climate shifts' in the past, e.g., in the mid-1980s and, in the SH, in late-1990s (Reid et al. 2016). Jones and Ricketts (2017) also identified a significant 'step change' in various global temperature datasets around 1997. More focussed studies of the SH have identified sharp changes around this period, for instance in South Pole temperature records (Clem et al. 2020) and Australian fire weather data (Harris and Lucas 2019). These localized changes are nested within larger global changes, and the shifts are often related to decadal-scale variations of SST such as the IPO. Given these large and abrupt changes, it is not unreasonable to expect similar signals within MMC metrics, and they provide further lines of evidence for the robustness of the changes found in this study even after accounting for the known concerns with the reanalysis data.

\section{Summary and conclusions}

This study investigates changes to the global mean meridional circulation (MMC) using the dry isentropic streamfunction $\Psi$, which presents a different view of the flow compared to the more common isobaric streamfunction calculation. In the isentropic framework, midlatitude large-scale weather systems are integrated into the MMC, resulting in a single thermally direct cell in each hemisphere. Data are taken from the ERA-I reanalysis for the period from 1979 through 2017.

From the full circulation, $\Psi$ is decomposed into steady and transient components. The steady component resembles aspects of the isobaric three-cell circulation and allows for the identification of the HC. The transient circulation is dominated by an overturning cell centred in the extratropics, representing the cumulative mass transports due to baroclinic waves. From these components, VMT profiles are computed along selected isentropes at all latitudes and all seasons. These VMT profiles reveal seven vertical branches of the MMC which were evaluated. The climatology and variability of these features were presented in this paper.

The ITCZ (or HC ascending branch) has seen no statistically significant trends in position; the intensity is increasing in all seasons, reaching statistically significant levels in JJA and SON. The HC descending branches indicate variable poleward expansion. Across both hemispheres, the largest rate of tropical expansion occurs in the local autumn, with the exception being JJA in the $\mathrm{NH}$; the latter is hypothesized to be linked to volcanic activity in the 1980s and 1990s and may not reflect the trend in the tropical width. The $\mathrm{HC}$ has intensified, particularly in the SH. The $\mathrm{NH}$ HC might have intensified in winter (DJF), but is associated with strong interannual variability with ENSO which means the signal is harder to detect.

The transient circulation, that capture processes of amplifying baroclinic waves associated with the polar front and the storm track, also shows marked variability in the SH. The transient updraft strength is quasi-steady prior to 1997, but after that it drops drastically to about $\sim 60 \%$ of its pre1997 value by 2000 before recovering to its pre-1997 value in the early 2010s. The changes are centred around $45^{\circ} \mathrm{S}$ and occur mostly in the mid to upper troposphere.

The rates of tropical expansion reported by this study are consistent with previous studies. The changes in the SH extratropical circulation, identified from the late 1990s, are particularly strong, with the mass transport declining by $2 \times 10^{10} \mathrm{~kg} \mathrm{~s}^{-1}$. While some uncertainty remains about the magnitude of these changes due to potential flaws in the dataset used, the coincidence of these changes with a number of changes in this period in non-reanalysis-based climatological studies advocates that they are plausible, not solely due to reanalysis issues.

Changes to the MMC have been attributed to some combination of forcing from anthropogenic greenhouse gases, the stratospheric 'ozone hole', aerosol forcing and/or sources of natural variability, for example through varying SSTs. Volcanic eruptions are also hypothesized to have a significant impact on the MMC, at least in the NH summer. The significant extratropical SH changes in the late 1990s appear to be strongly correlated with changes to the SST in the south-central Pacific Ocean, although some contribution from climate change cannot be discounted. Whether these MMC changes are a 'reaction to', 'co-evolution with', or 'cause of' these SST changes requires further investigation.

To our knowledge, it is the first study, where the dry isentropic streamfunction was used to evaluate branches of the MMC. Our follow-up paper will be focusing on the relationship of the MMC in the isentropic coordinates with the large-scale modes of variability and low stratospheric ozone. In the future, the use of a greater number of newer reanalysis products to cross check the results is necessary. Examining the MMC more thoroughly in alternative coordinative systems, such as the moist isentropic system, would provide useful insights into better understanding variability and change occurring in the subtropical and extratropical regions, where the water vapor accounts for half of the circulation intensity. Furthermore, we will explore links between regional meridional SST gradients and the intensity of related branches of the meridional circulation. Focusing on regional circulation patterns should also help to prove our hypothesis that monsoons are driving the near surface and mid-tropospheric MMC anomalies shown in Figs. 3,4,5.

Supplementary Information The online version contains supplementary material available at https://doi.org/10.1007/s00382-021-05903-9. 
Acknowledgements This work was partly funded by the Department of Environment, Land, Water and Planning through the Victorian Water and Climate Initiative. The authors would like to thank Linden Ashcroft, Sugata Narsey, Guomin Wang, David Jones and three anonymous reviewers for their insight and helpful comments that improved the manuscript. All data is available from the authors upon request.

Author contributions CL carried out the analysis and wrote the first draft. Other authors edited the manuscript. IR led the revision. All authors read and approved the final manuscript.

\section{Declarations}

Conflicts of interest The authors declare that they have no competing interests.

Open Access This article is licensed under a Creative Commons Attribution 4.0 International License, which permits use, sharing, adaptation, distribution and reproduction in any medium or format, as long as you give appropriate credit to the original author(s) and the source, provide a link to the Creative Commons licence, and indicate if changes were made. The images or other third party material in this article are included in the article's Creative Commons licence, unless indicated otherwise in a credit line to the material. If material is not included in the article's Creative Commons licence and your intended use is not permitted by statutory regulation or exceeds the permitted use, you will need to obtain permission directly from the copyright holder. To view a copy of this licence, visit http://creativecommons.org/licenses/by/4.0/.

\section{References}

Allen RJ, Kovilakam M (2017) The role of natural climate variability in recent tropical expansion. J Clim 30:6329-6350. https://doi. org/10.1175/JCLI-D-16-0735.1

Allen RJ, Norris JR, Kovilakam M (2014) Influence of anthropogenic aerosols and the Pacific Decadal Oscillation on tropical belt width. Nat Geosci 7:270-274. https://doi.org/10.1038/NGEO2 091

Amaya DJ, Siler N, Xie SP, Miller AJ (2017) The interplay of internal and forced modes of Hadley cell expansion: lessons from the global warming hiatus. Clim Dyn. https://doi.org/10.1007/ s00382-017-3921-5

Armour KC, Marshall J, Scott JR et al (2016) Southern Ocean warming delayed by circumpolar upwelling and equatorward transport. Nat Geosci 9:549-554. https://doi.org/10.1038/ngeo2731

Bengtsson L (2004) Can climate trends be calculated from reanalysis data? J Geophys Res 109:D11111. https://doi.org/10.1029/2004J D004536

Brönnimann S, Fischer AM, Rozanov E et al (2015) Southward shift of the northern tropical belt from 1945 to 1980 . Nat Geosci. https:// doi.org/10.1038/ngeo2568

Byrne MP, Pendergrass AG, Rapp AD, Wodzicki KR (2018) Response of the intertropical convergence zone to climate change: location, width, and strength. Curr Clim Chang Reports 4:355-370. https://doi.org/10.1007/s40641-018-0110-5

Cai W, Cowan T (2013) Southeast Australia autumn rainfall reduction: a climate-change-induced poleward shift of ocean-atmosphere circulation. J Clim. https://doi.org/10.1175/JCLI-D-12-00035.1

Cai W, Cowan T, Thatcher M (2012) Rainfall reductions over Southern Hemisphere semi-arid regions: the role of subtropical dry zone expansion. Sci Rep 2:702. https://doi.org/10.1038/srep00702
Chemke R, Dagan G (2018) The effects of the spatial distribution of direct anthropogenic aerosols radiative forcing on atmospheric circulation. J Clim 31:7129-7145. https://doi.org/10.1175/ JCLI-D-17-0694.1

Chemke R, Polvani LM (2019) Opposite tropical circulation trends in climate models and in reanalyses. Nat Geosci 12:528-532. https://doi.org/10.1038/s41561-019-0383-X

Chen X, Pauluis OM, Leung LR, Zhang F (2020) Significant contribution of mesoscale overturning to tropical mass and energy transport revealed by the ERA5 reanalysis. Geophys Res Lett. https://doi.org/10.1029/2019GL085333

Choi J, Son S-W, Park RJ (2019) Aerosol versus greenhouse gas impacts on Southern Hemisphere general circulation changes. Clim Dyn 52:4127-4142. https://doi.org/10.1007/ s00382-018-4370-5

Chou C, Chen CA (2010) Depth of convection and the weakening of tropical circulation in Global Warming. J Clim 23:3019-3030. https://doi.org/10.1175/2010JCLI3383.1

Clem KR, Fogt RL, Turner J et al (2020) Record warming at the South Pole during the past three decades. Nat Clim Chang. https://doi. org/10.1038/s41558-020-0815-z

Cohen J, Screen JA, Furtado JC et al (2014) Recent Arctic amplification and extreme mid-latitude weather. Nat Geosci 7:627-637

Coumou D, Petoukhov V, Rahmstorf S et al (2014) Quasi-resonant circulation regimes and hemispheric synchronization of extreme weather in boreal summer. Proc Natl Acad Sci 111:12331-12336. https://doi.org/10.1073/pnas.1412797111

D'Agostino R, Lionello P (2017) Evidence of global warming impact on the evolution of the Hadley Circulation in ECMWF centennial reanalyses. Clim Dyn. https://doi.org/10.1007/ s00382-016-3250-0

D’Agostino R, Lionello P, Adam O, Schneider T (2017) Factors controlling Hadley circulation changes from the Last Glacial Maximum to the end of the 21 st century. Geophys Res Lett $44: 8585$ 8591. https://doi.org/10.1002/2017GL074533

Davis N, Birner T (2017) On the discrepancies in tropical belt expansion between reanalyses and climate models and among tropical belt width metrics. J Clim 30:1211-1231. https://doi.org/10. 1175/JCLI-D-16-0371.1

Davis NA, Davis SM (2018) Reconciling Hadley cell expansion trend estimates in reanalyses. Geophys Res Lett. https://doi.org/10. 1029/2018GL079593

Davis SM, Rosenlof KH (2012) A multidiagnostic intercomparison of tropical-width time series using reanalyses and satellite observations. J Clim 25:1061-1078. https://doi.org/10.1175/ JCLI-D-11-00127.1

Dee DP, Uppala SM, Simmons AJ et al (2011) The ERA-Interim reanalysis: configuration and performance of the data assimilation system. Q J R Meteorol Soc 137:553-597. https://doi.org/10. $1002 /$ qj. 828

Dima IM, Wallace JM (2003) On the seasonality of the Hadley cell. J Atmos Sci 60:1522-1527. https://doi.org/10.1175/15200469(2003)060\%3c1522:OTSOTH\%3e2.0.CO;2

Döös K, Nilsson J (2011) Analysis of the meridional energy transport by atmospheric overturning circulations. J Atmos Sci 68:18061820. https://doi.org/10.1175/2010JAS3493.1

England MH, Mcgregor S, Spence P et al (2014) Recent intensification of wind-driven circulation in the Pacific and the ongoing warming hiatus. Nat Clim Chang 4:222-227. https://doi.org/10. 1038/nclimate2106

Frederiksen CS, Grainger S (2015) The role of external forcing in prolonged trends in Australian rainfall. Clim Dyn. https://doi.org/ $10.1007 / \mathrm{s} 00382-015-2482-8$

Freund MB, Henley BJ, Karoly DJ et al (2019) Higher frequency of Central Pacific El Niño events in recent decades 
relative to past centuries. Nat Geosci. https://doi.org/10.1038/ s41561-019-0353-3

Fu Q, Johanson CM, Wallace JM, Reichler T (2006) Enhanced midlatitude tropospheric warming in satellite measurements. Science 312:1179. https://doi.org/10.1126/science.1125566

Fyfe JC, Gillett NP, Zwiers FW (2013) Overestimated global warming over the past 20 years. Nat Clim Chang 3:767-769. https://doi. org/10.1038/nclimate1972

Garfinkel CI, Waugh DW, Polvani LM (2015) Recent Hadley cell expansion: the role of internal atmospheric variability in reconciling modeled and observed trends. Geophys Res Lett . https:// doi.org/10.1002/2015GL066942

Gerber EP, Son SW (2014) Quantifying the summertime response of the Austral jet stream and Hadley cell to stratospheric ozone and greenhouse gases. J Clim. https://doi.org/10.1175/ JCLI-D-13-00539.1

Grassi B, Redaelli G, Canziani PO, Visconti G (2012) Effects of the PDO phase on the tropical belt width. J Clim 25:3282-3290. https://doi.org/10.1175/JCLI-D-11-00244.1

Grise KM, Davis SM (2020) Hadley cell expansion in CMIP6 models. Atmos Chem Phys 20:5249-5268. https://doi.org/10.5194/ acp-20-5249-2020

Grise KM, Davis SM, Staten PW, Adam O (2018) Regional and seasonal characteristics of the recent expansion of the tropics. $\mathrm{J}$ of Clim 31:6839-6856

Grise KM, Davis SM, Simpson IR et al (2019) Recent tropical expansion: natural variability or forced response? J Clim 32:15511571. https://doi.org/10.1175/JCLI-D-18-0444.1

Harris S, Lucas C (2019) Understanding the variability of Australian fire weather between 1973 and 2017. PLoS ONE. https://doi.org/ 10.1371/journal.pone.0222328

Held IM, Schneider T (1999) The surface branch of the zonally averaged mass transport circulation in the troposphere. J Atmos Sci 56:1688-1697. https://doi.org/10.1175/1520-0469(1999)056\% 3c1688:TSBOTZ\%3e2.0.CO;2

Held IM, Soden BJ (2006) Robust responses of the hydrological cycle to global warming. J Clim 19:5686-5699. https://doi.org/10. 1175/JCLI3990.1

Henley BJ, Gergis J, Karoly DJ et al (2015) A Tripole Index for the Interdecadal Pacific Oscillation. Clim Dyn 45:3077-3090. https://doi.org/10.1007/s00382-015-2525-1

Hersbach H, Bell B, Berrisford P et al (2020) The ERA5 global reanalysis. Q J R Meteorol Soc 146:1999-2049. https://doi.org/10. 1002/qj.3803

Hoskins BJ, Yang GY, Fonseca RM (2020) The detailed dynamics of the June-August Hadley Cell. Q J R Meteorol Soc 146:557-575. https://doi.org/10.1002/qj.3702

Hu Y, Fu Q (2007) Observed poleward expansion of the Hadley circulation since 1979. Atmos Chem Phys Discuss 7:9367-9384. https://doi.org/10.5194/acpd-7-9367-2007

Huber M, Knutti R (2014) Natural variability, radiative forcing and climate response in the recent hiatus reconciled. Nat Geosci. https:// doi.org/10.1038/ngeo2228

Jones RN, Ricketts HJ (2017) Reconciling the signal and noise of atmospheric warming on decadal timescales. Earth Syst Dyn 8:177-210. https://doi.org/10.5194/esd-8-177-2017

Juckes MN, James IN, Blackburn M (1994) The influence of Antarctica on the momentum budget of the southern extratropics. Q J R Meteorol Soc 120:1017-1044. https://doi.org/10.1002/qj.49712 051811

Kang SM, Lu J (2012) Expansion of the Hadley Cell under Global Warming: Winter versus Summer. J Clim 25:8387-8393. https:// doi.org/10.1175/JCLI-D-12-00323.1

Kjellsson J, Döös K, Laliberté FB, Zika JD (2014) The Atmospheric General Circulation in Thermodynamical Coordinates. J Atmos Sci 71:916-928. https://doi.org/10.1175/JAS-D-13-0173.1
Kosaka Y, Xie S-P (2016) The tropical Pacific as a key pacemaker of the variable rates of global warming. Nat Geosci 9:669-673. https://doi.org/10.1038/ngeo2770

Kostov Y, Marshall J, Hausmann U et al (2017) Fast and slow responses of Southern Ocean sea surface temperature to SAM in coupled climate models. Clim Dyn 48:1595-1609. https://doi.org/10. 1007/s00382-016-3162-z

Kovilakam M, Mahajan S (2015) Black carbon aerosol-induced Northern Hemisphere tropical expansion. Geophys Res Lett 42:49644972. https://doi.org/10.1002/2015GL064559

Krueger AJ, Walter LS, Schnetzler CC, Doiron SD (1990) TOMS measurement of the sulfur dioxide emitted during the 1985 Nevado del Ruiz eruptions. J Volcanol Geotherm Res 41:7-15. https://doi.org/10.1016/0377-0273(90)90081-P

Laliberte F, Shaw T, Pauluis O (2012) Moist recirculation and water vapor transport on dry isentropes. J Atmos Sci 69:875-890. https://doi.org/10.1175/Jas-D-11-0124.1

Levine XJ, Schneider T (2015) Baroclinic eddies and the extent of the Hadley circulation: an idealized GCM study. J Atmos Sci 72:2744-2761. https://doi.org/10.1175/JAS-D-14-0152.1

Ling J, Zhang C (2013) Diabatic heating profiles in recent global reanalyses. J Clim 26:3307-3325. https://doi.org/10.1175/ JCLI-D-12-00384.1

Liu W, Xie SP, Lu J (2016) Tracking ocean heat uptake during the surface warming hiatus. Nat Commun 7:1-9. https://doi.org/10. 1038/ncomms 10926

Loeb NG, Rutan DA, Kato S, Wang W (2014) Observing interannual variations in Hadley circulation atmospheric diabatic heating and circulation strength. J Clim 27:4139-4158. https://doi.org/ 10.1175/JCLI-D-13-00656.1

Lu J, Vecchi GA, Reichler T (2007) Expansion of the Hadley cell under global warming. Geophys Res Lett 34:L06805. https://doi.org/ 10.1029/2006GL028443

Lucas C, Nguyen H (2015) Regional characteristics of tropical expansion and the role of climate variability. J Geophys Res Atmos 120:6809-6824. https://doi.org/10.1002/2015JD023130

Lucas C, Nguyen H, Timbal B (2012) An observational analysis of Southern Hemisphere tropical expansion. J Geophys Res Atmos 117:1-18. https://doi.org/10.1029/2011JD017033

Lucas C, Timbal B, Nguyen H (2014) The expanding tropics: a critical assessment of the observational and modeling studies. Wiley Interdiscip Rev Clim Chang 5:89-112. https://doi.org/10.1002/ wcc. 251

MacKellar N, New M, Jack C (2014) Observed and modelled trends in rainfall and temperature for South Africa: 1960-2010. S Afr J Sci 110:1-13. https://doi.org/10.1590/sajs.2014/20130353

Meehl GA, Hu A, Arblaster JM et al (2013) Externally forced and internally generated decadal climate variability associated with the interdecadal pacific oscillation. J Clim. https://doi.org/10. 1175/JCLI-D-12-00548.1

Min S-K, Son S-W (2013) Multimodel attribution of the Southern Hemisphere Hadley cell widening: Major role of ozone depletion. J Geophys Res Atmos 118:3007-3015. https://doi.org/10. 1002/jgrd.50232

Ming Y, Ramaswamy V (2011) A model investigation of AerosolInduced changes in tropical circulation. J Clim 24:5125-5133. https://doi.org/10.1175/2011JCLI4108.1

Nakamura N (1995) Modified Lagrangian-mean diagnostics of the stratospheric polar vortices. Part I. Formulation and analysis of GFDL SKYHI GCM. J Atmos Sci 52:2096-2108. https://doi.org/ 10.1175/1520-0469(1995)052\%3c2096:MLMDOT\%3e2.0.CO;2

Naranjo JL, Sigurdsson H, Carey SN, Fritz W (1986) Eruption of the Nevado del Ruiz volcano, Colombia, on 13 November 1985: Tephra fall and lahars. Science 233:961-963. https://doi.org/10. 1126/science.233.4767.961 
Nguyen H, Evans A, Lucas C et al (2013) The Hadley circulation in reanalyses: climatology, variability, and change. J Clim 26:33573376. https://doi.org/10.1175/JCLI-D-12-00224.1

Nguyen H, Lucas C, Evans A et al (2015) Expansion of the southern hemisphere Hadley cell in response to greenhouse gas forcing. J Clim 28:8067-8077. https://doi.org/10.1175/JCLI-D-15-0139.1

Oort AH, Yienger JJ (1996) Observed interannual variability in the Hadley circulation and its connection to ENSO. J Clim 9:27512767. https://doi.org/10.1175/1520-0442(1996)009\%3c2751: OIVITH\%3e2.0.CO;2

Pauluis O, Czaja A, Korty R (2008) The global atmospheric circulation on moist isentropes. Science. https://doi.org/10.1126/scien ce. 1159649

Pauluis O, Czaja A, Korty R (2010) The global atmospheric circulation in moist isentropic coordinates. J Clim 23:3077-3093. https:// doi.org/10.1175/2009JCLI2789.1

Pausata FSR, Zanchettin D, Karamperidou C et al (2020) ITCZ shift and extratropical teleconnections drive ENSO response to volcanic eruptions. Sci Adv. https://doi.org/10.1126/sciadv.aaz5006

Polvani LM, Waugh DW, Correa GJP, Son S-W (2011) Stratospheric ozone depletion: the main driver of twentieth-century atmospheric circulation changes in the southern hemisphere. J Clim 24:795-812. https://doi.org/10.1175/2010JCLI3772.1

Quan XW, Hoerling MP, Perlwitz J et al (2014) How fast are the tropics expanding? J Clim 27:1999-2013. https://doi.org/10.1175/ JCLI-D-13-00287.1

Reichler T, Dameris M, Sausen R (2003) Determining the tropopause height from gridded data. Geophys Res Lett 30:2042. https://doi. org/10.1029/2003GL018240

Reid PC, Hari RE, Beaugrand G et al (2016) Global impacts of the 1980s regime shift. Glob Chang Biol 22:682-703. https://doi. org/10.1111/gcb.13106

Risbey JS, Pook MJ, McIntosh PC et al (2009) On the remote drivers of rainfall variability in Australia. Mon Weather Rev 137:32333253. https://doi.org/10.1175/2009MWR2861.1

Robertson AW, Vitart F (2019) Sub-seasonal to seasonal prediction: the gap between weather and climate forecasting. Elsevier, Amsterdam

Robock A (2000) Volcanic eruptions and climate. Rev Geophys 38:191-219. https://doi.org/10.1029/1998RG000054

Rotstayn LD, Lohmann U (2002) Tropical rainfall trends and the indirect aerosol effect. J Clim 15:2103-2116. https://doi.org/10.1175/ 1520-0442(2002)015\%3c2103:TRTATI\%3e2.0.CO;2

Rudeva I, Simmonds I, Crock D, Boschat G (2019) Midlatitude fronts and variability in the Southern Hemisphere tropical width. J Clim 32:8243-8260. https://doi.org/10.1175/JCLI-D-18-0782.1

Schneider T (2006) The general circulation of the atmosphere. Annu Rev Earth Planet Sci 34:655-688. https://doi.org/10.1146/annur ev.earth.34.031405.125144

Schneider T, Smith K, O'Gorman PA, Walker CC (2006) A climatology of tropospheric zonal-mean water vapor fields and fluxes in isentropic coordinates. J Clim 19:5918-5933. https://doi.org/10. 1175/JCLI3931.1

Seidel DJ, Randel WJ (2007) Recent widening of the tropical belt: Evidence from tropopause observations. J Geophys Res 112:D20113. https://doi.org/10.1029/2007JD008861

Seidel DJ, Fu Q, Randel WJ, Reichler TJ (2008) Widening of the tropical belt in a changing climate. Nat Geosci 1:21-24. https://doi. org/10.1038/ngeo.2007.38

Seo KH, Frierson DMW, Son JH (2014) A mechanism for future changes in Hadley circulation strength in CMIP5 climate change simulations. Geophys Res Lett. https://doi.org/10.1002/2014G L060868

Serreze MC, Barry RG (2011) Processes and impacts of Arctic amplification: a research synthesis. Glob Planet Change 77:85-96. https://doi.org/10.1016/j.gloplacha.2011.03.004
Shaw TA, Pauluis O (2012) Tropical and subtropical meridional latent heat transports by disturbances to the zonal mean and their role in the general circulation. J Atmos Sci 69:1872-1889. https://doi. org/10.1175/JAS-D-11-0236.1

Simmons AJ, Poli P, Dee DP et al (2014) Estimating low-frequency variability and trends in atmospheric temperature using ERAInterim. Q J R Meteorol Soc 140:329-353. https://doi.org/10. 1002/qj.2317

Škerlak B, Sprenger M, Wernli H (2014) A global climatology of stratosphere-troposphere exchange using the ERA-Interim data set from 1979 to 2011. Atmos Chem Phys 14:913-937. https:// doi.org/10.5194/acp-14-913-2014

Škerlak B, Sprenger M, Pfahl S et al (2015) Tropopause folds in ERAinterim: global climatology and relation to extreme weather events. J Geophys Res 120:4860-4877. https://doi.org/10.1002/ 2014JD022787

Solman SA, Orlanski I (2016) Climate change over the extratropical Southern Hemisphere: The tale from an ensemble of reanalysis datasets. J Clim. https://doi.org/10.1175/JCLI-D-15-0588.1

Solomon A, Polvani LM, Waugh DW, Davis SM (2016) Contrasting upper and lower atmospheric metrics of tropical expansion in the Southern Hemisphere. Geophys Res Lett. https://doi.org/10. 1002/2016GL070917

Son S-W, Gerber EP, Perlwitz J et al (2010) Impact of stratospheric ozone on southern hemisphere circulation change: a multimodel assessment. J Geophys Res. https://doi.org/10.1029/2010JD0142 71

Staten PW, Lu J, Grise KM et al (2018) Re-examining tropical expansion. Nature Clim Change 8:768-775. https://doi.org/10.1038/ s41558-018-0246-2

Staten PW et al (2020) Tropical widening: from global variations to regional impacts. Bull Amer Meteor Soc 101:E897-E904. https://doi.org/10.1175/BAMS-D-19-0047.1

Tanaka D, Iwasaki T, Uno S et al (2004) Eliassen-palm flux diagnosis based on isentropic representation. J Atmos Sci 61:2370-2383. https://doi.org/10.1175/1520-0469(2004)061\%3c2370:EFDBOI\%3e2.0.CO;2

Thomason LW, Ernest N, Millán L et al (2018) A global space-based stratospheric aerosol climatology: 1979-2016. Earth Syst Sci Data 10:469-492. https://doi.org/10.5194/essd-10-469-2018

Thorne PW, Vose RS (2010) Reanalyses suitable for characterizing long-term trends. Bull Am Meteorol Soc 91:353-361. https:// doi.org/10.1175/2009BAMS2858.1

Townsend RD, Johnson DR (1985) A diagnostic study of the isentropic zonally averaged mass circulation during the first GARP global experiment. J Atmos Sci 42:1565-1579

Trenberth KE, Fasullo JT (2013) An apparent hiatus in global warming? Earth's Futur. https://doi.org/10.1002/2013ef000165

Trenberth KE, Stepaniak DP (2003) Seamless poleward atmospheric energy transports and implications for the Hadley circulation. J Clim 16:3706-3722. https://doi.org/10.1175/1520-0442(2003) 016\%3c3706:SPAETA\%3e2.0.CO;2

Turton SM (2017) Expansion of the tropics: revisiting frontiers of geographical knowledge. Geogr Res 55:3-12. https://doi.org/ 10.1111/1745-5871.12230

Vernier JP, Thomason LW, Pommereau JP et al (2011) Major influence of tropical volcanic eruptions on the stratospheric aerosol layer during the last decade. Geophys Res Lett 38:1-8. https://doi.org/ 10.1029/2011GL047563

Waliser DE, Gautier C (1993) A Satellite-derived Climatology of the ITCZ. J Clim 6:2162-2174. https://doi.org/10.1175/15200442(1993)006\%3c2162:ASDCOT\%3e2.0.CO;2

Watt Meyer O, Frierson DMW, Fu Q (2019) Hemispheric asymmetry of tropical expansion under CO2 forcing. Geophys Res Lett 46:9231-9240. https://doi.org/10.1029/2019GL083695 
Waugh DW, Grise KM, Seviour WJM et al (2018) Revisiting the relationship among metrics of tropical expansion. J Clim 31:75657581. https://doi.org/10.1175/JCLI-D-18-0108.1

Wills RC, Schneider T, Wallace JM et al (2018) Disentangling global warming, multidecadal variability, and El Niño in pacific temperatures. Geophys Res Lett 45:2487-2496. https://doi.org/10. 1002/2017GL076327

Wodzicki KR, Rapp AD (2016) Long-term characterization of the pacific ITCZ using TRMM GPCP, and ERA-Interim. J Geophys REs. https://doi.org/10.1002/2015JD024458
Wu Y, Lu J, Pauluis O (2019) Weakening of upward mass but intensification of upward energy transport in a warming climat. Geophys Res Lett 46:1672-1680. https://doi.org/10.1029/2018GL081399

Publisher's Note Springer Nature remains neutral with regard to jurisdictional claims in published maps and institutional affiliations. 